\title{
Structural evidence of in-sequence and out-of-sequence thrusting in the Karwendel mountains and the tectonic subdivision of the western Northern Calcareous Alps
}

\author{
Sinah KILIAN and Hugo ORTNER \\ Institute of Geology, University of Innsbruck, Innrain 52, 6020 Innsbruck, Austria \\ Corresponding author: Sinah.Kilian@student.uibk.ac.at
}

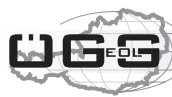

KEYWORDS Northern Calcareous Alps, Karwendel, out-of-sequence thrusting, thrust boundary, Austria, Tirol

\begin{abstract}
We present the results of a field study in the Karwendel mountains in the western Northern Calcareous Alps, where we analysed the boundary between two major thrust sheets in detail in a key outcrop where nappe tectonics had been recognized already at the beginning of the 20th century. We use the macroscopic structural record of thrust sheet transport in the footwall and hanging wall of this boundary, such as folds, foliation and faults. In the footwall, competent stratigraphic units tend to preserve a full record of deformation while incompetent units get pervasively overprinted and only document the youngest deformation.

Transport across the thrust persisted throughout the deformation history of the Northern Calcareous Alps from the late Early Cretaceous to the Miocene. As a consequence of transtensive, S-block down strike-slip tectonics, postdating folding of the major thrust, new out-of-sequence thrusts formed that climbed across the step, and ultimately placed units belonging to the footwall of the initial thrust onto its hanging wall.

One of these out-of-sequence thrusts had been used to delimit the uppermost large thrust sheet (Inntal thrust sheet) of the western Northern Calcareous against the next, tectonically deeper, (Lechtal) thrust sheet. Based on the structural geometry of the folded thrust and the age of the youngest sediments below the thrust, we redefine the thrust sheets, and name the combined former Inntal- and part of the Lechtal thrust sheet as the new Karwendel thrust sheet and the former Allgäu- and part of the Lechtal thrust sheet as the new Tannheim thrust sheet.
\end{abstract}

\section{Introduction}

\subsection{Background and aim of the study}

The Northern Calcareous Alps (NCA) represent the sedimentary cover of the topmost tectonic unit of the Austroalpine nappe system that represents the upper plate in the Alpine orogen (e.g. Schmid et al., 2004; Tollmann, 1976b). The thrust sheets of the NCA were defined at the beginning of the 20th century by Ampferer and Hammer (1911) and Ampferer (1912) in the western NCA, and by Hahn $(1912 ; 1913)$ in the central and eastern NCA. Their classifications are in use ever since. In his review of the structure of the NCA, Tollmann (1970; 1976b) unified the classifications and defined a system of far-travelled nappes. In the western NCA, these thrust sheets are from base to top the Allgäu-, the Lechtal- and the Inntal thrust sheets (Fig. 1). Ever since this subdivision was proposed, it was controversially debated, especially the boundary of the Inntal- against the Lechtal thrust sheet (Ampferer, 1912; 1914; 1931; 1942; Heißel, 1958; Loesch, 1915; Mylius, 1914; Richter, 1929; Rüffer and Bechstädt, 1995; Schlagintweit, 1912a; b) in the western NCA. Based on earlier tectonic sketches by Ampferer and Heißel (1950) and Heißel (1958), Tollmann defined a frontal slice of the Inntal thrust sheet (Karwendel-Stirnschuppe; Tollmann, 1970). Heißel $(1977 ; 1978)$ and Donofrio et al. (1980) redefined the boundaries of the Inntal thrust sheet, and included this frontal slice in the Karwendel zone of slices (Karwendelschuppenzone) on which the Inntal thrust sheet was emplaced. Later studies, for example, Eisbacher and Brandner (1995; 1996), Eisbacher et al. (1990), Tanner et al. (2003) used the nappe subdivision of Tollmann (1976b) even though new and clearer concepts had been developed to describe fold-and-thrust belts (Boyer and Elliott, 1982; Dahlstrom, 1969; Suppe, 1983).

In the last years, serious doubts (re)emerged about the validity of the nappe subdivision of the western NCA as proposed by Tollmann (1976b). Part of the problems result from the out-of-sequence nature of some principal thrusts of the NCA (Ortner, 2003a). This study discusses the thrust sheet boundaries in the Karwendel mountains of the western NCA, revaluates these boundaries and proposes a new subdivision.

\subsection{Terminology}

For many years, nappes and thrust sheets were defined without clear definitions of the exact meaning of the terms used. An attempt has been made by Tollmann (1973), but unfortunately the terminology proposed was not applied systematically. Much of the abovementioned controversy resulted from the fact that all authors tried to define nappes that are separated on all sides from the tectonically deeper unit by a basal thrust. This neglects 

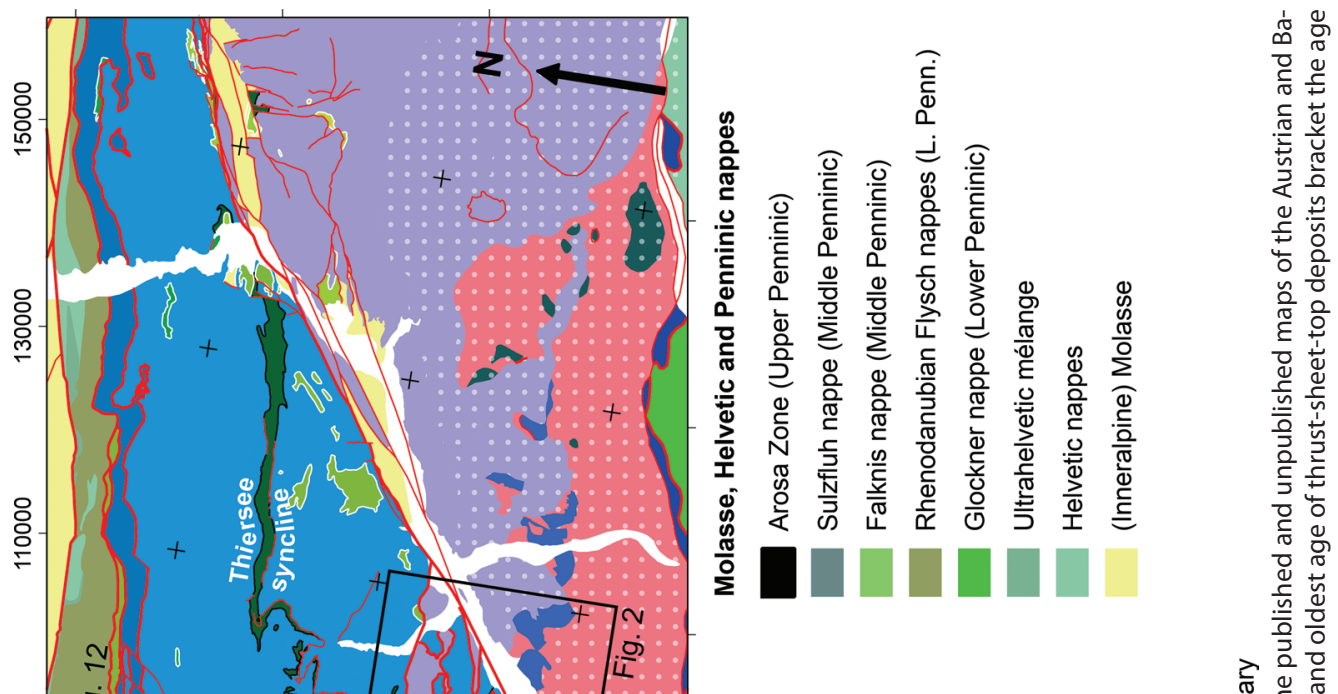

离

空

ㅇํㅇ

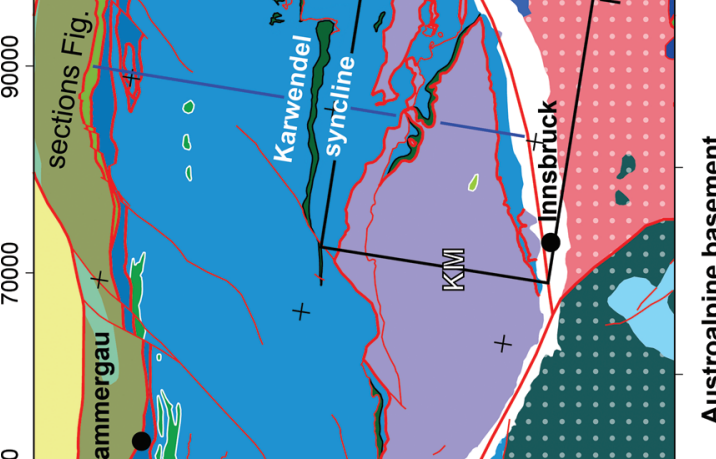

:

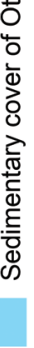

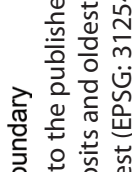

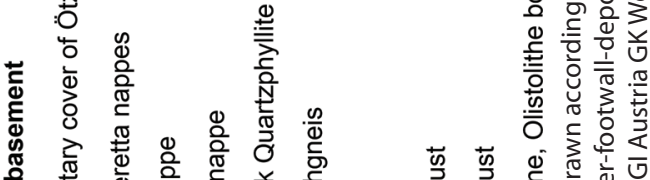
ब

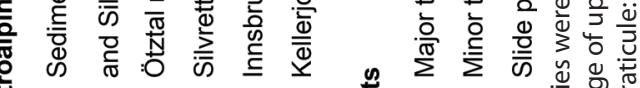

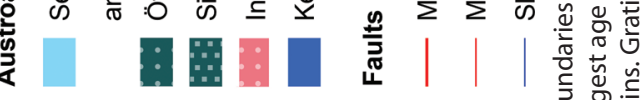

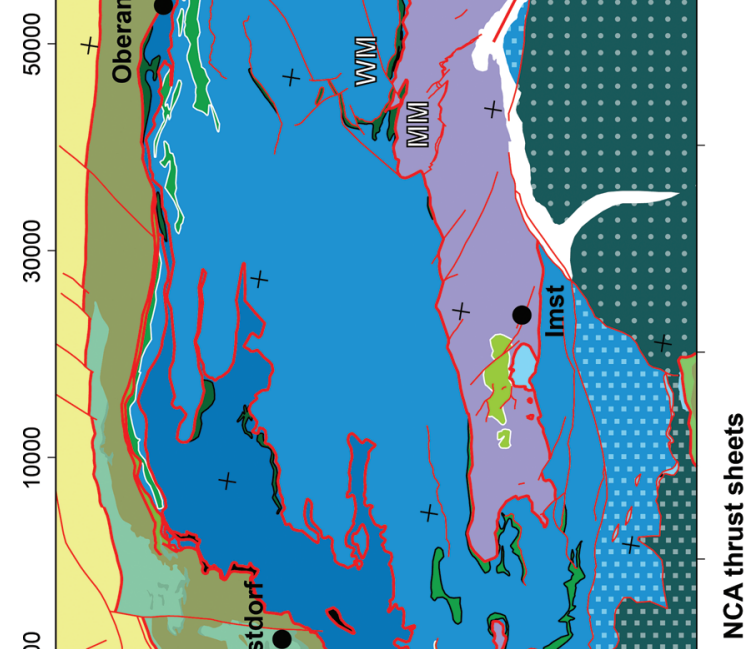

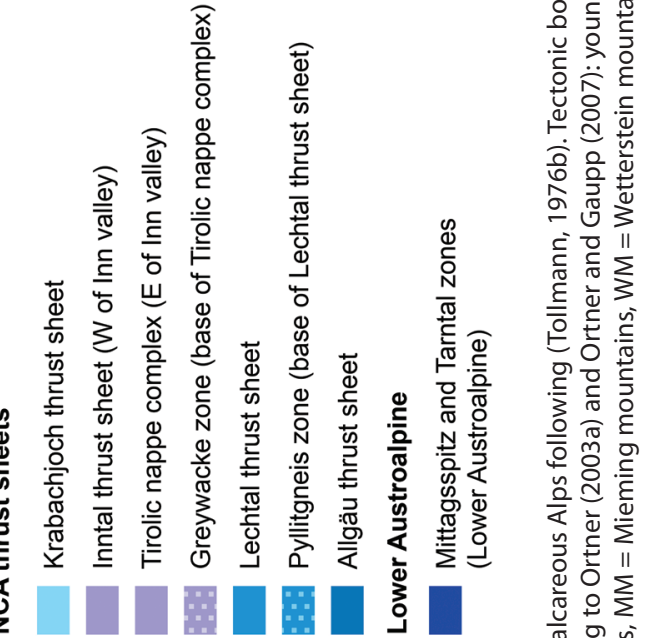

亏

늘

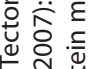

केㅇㅇ을

웡

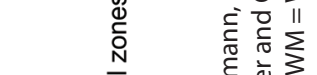

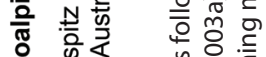

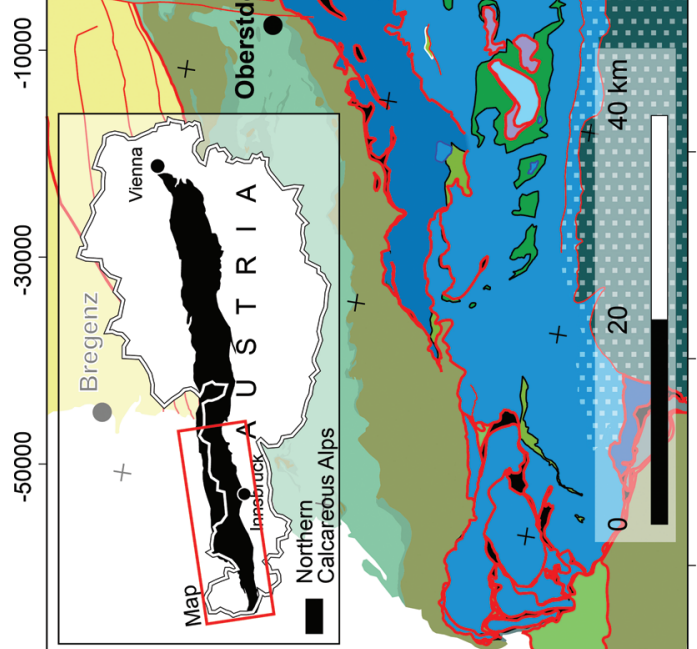

(ब 000092 $0000 t z$ $0000 z 2$

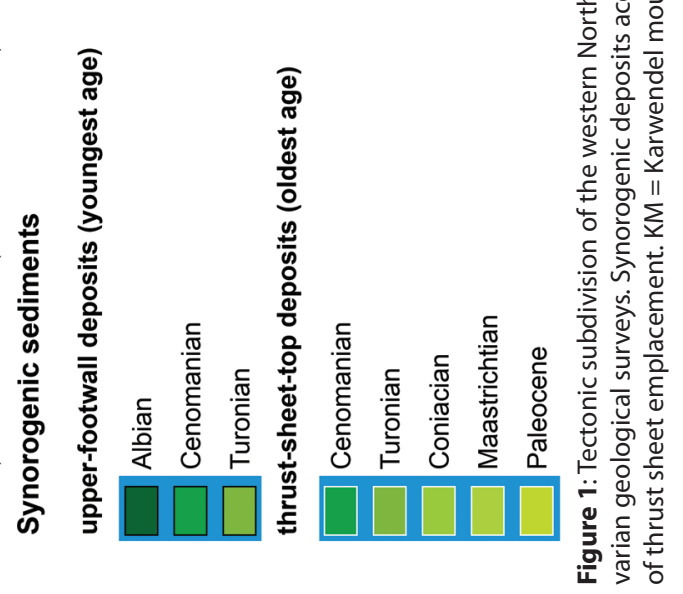


the fact that, in an early stage, thrusts nucleate with a limited extent, and then continue to grow laterally while offset increases. Therefore, an allochthon will be far-travelled near the centre of the basal thrust, whereas offset will diminish or disappear at the end of the thrust. It also neglects the possibility of out-of-sequence thrusting, that is, thrusts cutting across existing structures like folds or older thrusts.

Here, we use following definitions: A thrust is a low-angle fault that superimposes older on younger rocks. Out-ofsequence thrusts are thrusts that develop in the hanging wall or hinterland of an older thrust and cut across older thrust-related structures. They may emplace younger on older rocks. Thrusts and out-of-sequence thrusts may be of high angle as a consequence of subsequent folding of the thrust.

\subsection{Tectonic evolution of the Northern Calcareous Alps}

The Permian to Triassic sediments of the NCA were deposited on the passive continental margin of Eurasia, which was then part of Pangea, towards the Meliata branch of the Neotethys ocean (e.g. Haas et al., 1995; Lein, 1987; Schmid et al., 2004; Stampfli et al., 1998). Shallow to deep marine successions accumulated on this continental margin (Mandl, 2000). Early Jurassic rifting initiated opening of the Penninic ocean, and the Adriatic plate, including the future NCA, was separated from Eurasia (Froitzheim and Manatschal, 1996). The new continental margins drowned, ending shallow marine deposition, and pelagic sediments settled throughout the Jurassic and Early Cretaceous. Upper Albian basanitic dykes and sills locally intruded these sediments (Richter, 1928; Trommsdorff et al., 1990).

Alpine orogeny is related to the closure of the two neighbouring oceans (Froitzheim et al., 1996): (1) Cretaceous (Eoalpine) orogeny occurred after obduction of Meliata ophiolites onto the southeastern Adriatic margin, with the Austroalpine, Adria-derived units being in lower plate position (Schmid et al., 2004; Stüwe and Schuster, 2010). Stacking of thrust sheets in the studied part of the NCA started at the end of the Albian based on the age of the youngest sediments (Eisbacher and Brandner, 1996; Ortner, 2003a). (2) Paleogene (Mesoalpine) orogeny was related to the extinction of the Penninic ocean in the Late Eocene, and this time the Austroalpine, including the NCA, was in upper plate position (Schmid et al., 2004; Stüwe and Schuster, 2010). Within the internal Austroalpine basement units, Eoalpine and Mesoalpine stacking is clearly separated by Upper Cretaceous extension (Froitzheim et al., 1994), but in the external thrust sheets, Cretaceous to Cenozoic shortening is continuous, as documented by growth strata in different synorogenic successions (Ortner, 2001; 2003a; Ortner and Gaupp, 2007; Ortner et al., 2016).

The age of movement of individual thrust sheets during Cretaceous nappe stacking can be deduced using the youngest sediments below a thrust and retransgression on top of the thrust sheet during and after emplacement (Ortner, 2003a; 2016; Ortner and Gaupp, 2007). Nappe stacking in the western NCA started in Albian by imbrication of the Lechtal thrust sheet onto the Allgäu thrust sheet and propagated progressively into the more external parts of the NCA fold-and-thrust belt, incorporating the Cenomanrandschuppe and the Penninic Arosa Zone in the Turonian to Coniacian, and the Rhenodanubian Flysch nappes in the Maastrichtian (Ortner, 2003a). However, post-Cenomanian stacking of the Inntal- onto the Lechtal thrust sheet post-dated emplacement of the Lechtal thrust sheet, and was out-of-sequence (Ortner, 2003a). Eoalpine, mid-Cretaceous nappe stacking, transport and folding was NW directed to NNW directed, whereas subsequent Mesoalpine Late Cretaceous to Paleogene shortening was $\mathrm{N}$ to NNE directed (Eisbacher and Brandner, 1996; Ortner, 2003b). Neoalpine late Paleogene to Neogene shortening was NW to NE directed and repeated the Cretaceous-Paleogene history in terms of directions (Ortner, 2003b; Peresson and Decker, 1997)

\section{Investigated area}

In the studied area (see Appendix for the geologic map), the Karwendel thrust between the Inntal- and the Lechtal thrust sheets is spectacularly exposed below the north-facing cliffs of the Laliderer Wände, and at the western and eastern side of the DreizinkenspitzeGumpenspitze-Gamsjoch ridge (Fig. 2). These outcrops were already described and drawn in cross section by Ampferer (1902), and the thrust termed the Karwendel thrust. All overturned and/or faulted units below the main thrust sheet boundary are part of the Karwendel zone of slices (Fig. 2; Heißel, 1977; Heißel, 1978).

\section{Lithology}

The sedimentary succession in the Karwendel mountains reaches from the Upper Permian Haselgebirge to the Upper Triassic Hauptdolomit in the tectonically higher Inntal thrust sheet, and from the Hauptdolomit to the Cretaceous Schrambach Fm. in the underlying Lechtal thrust sheet (c.f. Fig. 3).

\subsection{Permo-Triassic sediments}

The oldest sediment in this part of the NCA is the Haselgebirge, which crops out in the direct vicinity of the study area (e.g. Mahnkopf, Halltal, Sulzgraben in west, south and east of the study area, respectively; Heißel, 1978; see Fig. 2). Discontinuous grey shales, cellular dolomites and reddish to greenish quartz-rich sandstones are found in surface outcrops. In the subsurface, large amounts of anhydrite and gypsum are known and salt has been mined (e.g. Schmidegg, 1950). The Haselgebirge is in contact to cellular dolomites and stromatolithic dolomites and limestones of the Reichenhall Fm. Above the last cellular dolomites, well-bedded micritic limestones prevail that are often strongly bioturbated ("Wurstelkalk" of the Virgloria Fm.) and have crinoids. Crinoidal arenites, bioclastic packstones with green algae and occasionally massive 


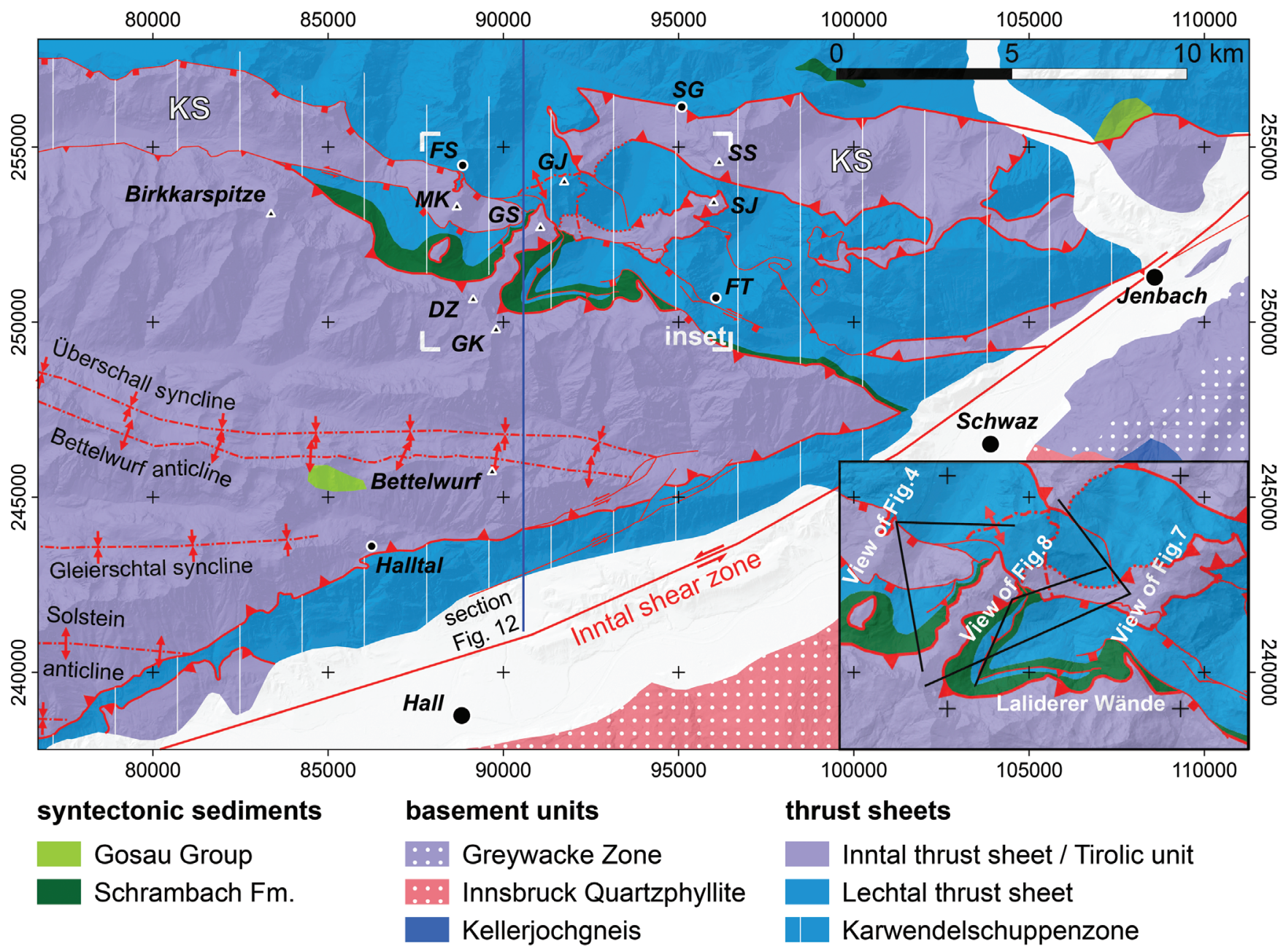

\section{faults $\_$major thrust $\quad \longrightarrow$ minor thrust 专. axial plane of syncline/anticline $\cong$ sinistral strike-slip fault}

Figure 2: Tectonic map of the eastern Karwendel mountains, using the subdivision of thrust sheets of Tollmann (1976b). Localities mentioned in text: DZ $=$ Dreizinkenspitze, FS = Falkenstand, FT = Falzthurntal, GJ = Gamsjoch, GS = Gumpenspitze, GK = Grubenkarspitze, MK = Mahnkopf, SG = Sulzgraben, SJ = Sonnjoch, SS = Schaufelspitze. Extent of Karwendel zone of slices (Karwendelschuppenzone) taken from Heißel (1978). KS = frontal slice of Inntal thrust sheet (Karwendel-Stirnschuppe) of Tollmann (1970). Graticule: MGI Austria GK West (EPSG: 31254).

limestones build the carbonate ramp of the Steinalm Fm. (Nittel, 2006; Rüffer and Zamperelli, 1997). Break-up of this carbonate ramp initiates facies differentiation between basins filled by nodular cherty filament-bearing limestones intercalated with tuff layers of the Reifling Fm. (Brühwiler et al., 2007; Nittel, 2006), and the Wetterstein carbonate platform. Clinoforms in the lower Wetterstein limestone interfinger with the Reifling Fm. in the study area. The Wetterstein carbonate platform is more than $1700 \mathrm{~m}$ thick (Sarnthein, 1966; 1967), and the Alpine Muschelkalk Group (Virgloria-, Steinalm- and Reifling Fms.) $150 \mathrm{~m}$ in the study area (Nittel, 2006). These units are the "competent backbone" of the Inntal thrust sheet, whereas the décollement lies in the evaporitic units, that is, cellular dolomites, anhydrite and salt of Reichenhall Fm. and Haselgebirge.

The Raibl beds, a succession of limestones, shales, dolomites and cellular dolomites (Jerz, 1966), that should follow on top of the Wetterstein limestone are not preserved in the study area. Another carbonate platform, the
Norian Hauptdolomit, well bedded, partly stromatolithic dolomite (Fruth and Scherreiks, 1982; Müller-Jungbluth, 1971), is the oldest exposed unit of the Lechtal thrust sheet. Towards the top, the Hauptdolomit platform drowns, and the Plattenkalk was deposited in a subtidal environment (Müller-Jungbluth, 1971). Drowning culminates in establishment of the basins of the Kössen Fm. during the Rhaetian. The Kössen marls and marly limestones interfinger with a platform, the Upper Rhaetian limestone. Black, dm to $1 / 2 \mathrm{~m}$ bedded limestones characterize the Kössen Fm. of the Lechtal thrust sheet in the study area, and these are comparable to the appearance of these units in the Allgäu thrust sheet in the northwestern part of the NCA (facies of the type Kalkalpen-Nordrand of Fabricius, 1966).

\subsection{Jurassic and Cretaceous sediments}

The turn from the Triassic to the Jurassic is a major transition in the stratigraphic and tectonic evolution of the NCA ("Adneter Wende"; Schlager and Schöllnberger, 


\section{Sedimentary succession}
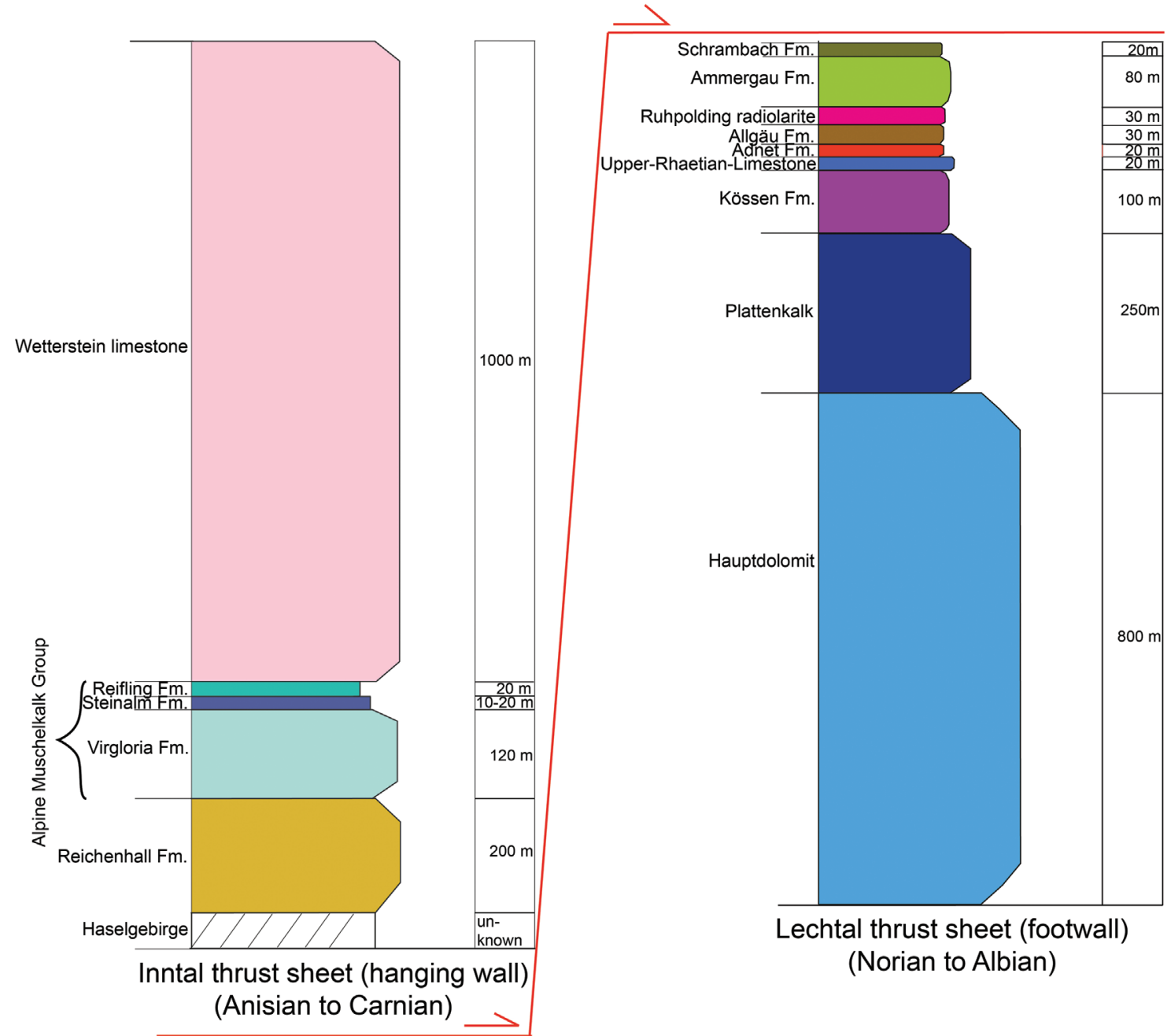

Figure 3: Sedimentary succession of the Inntal and the Lechtal thrust sheets, and thickness of the deposits.

1974). Onset of Penninic rifting caused drowning of the Triassic carbonate platforms and major subsidence, and rift-related normal faulting caused facies differentiation (e.g. Nagel et al., 1976). The Adnet Fm., condensed red nodular, micritic limestones, represents submarine highs, whereas the Allgäu Fm. was deposited in basins and reaches more than $1 \mathrm{~km}$ thickness (Jacobshagen, 1965). Synrift deposition ends at the turn to the Upper Jurassic with the "Ruhpoldinger Wende" (Schlager and Schöllnberger, 1974) when the variegated cherts of the Ruhpolding radiolarite accumulated. The Upper Jurassic to Lower Cretaceous Ammergau Fm. consists of dense pelagic, sometimes marly, well bedded, micritic limestones intercalated with thin marl layers (Tollmann, 1976a). The Lower Cretaceous (Berriasian to Albian) Schrambach Fm. consists of marls intercalated with marls and, occasionally, sandstones (Nagel et al., 1976).

\section{Results}

Here, we describe the structures observed in the Gumpenspitze-Gamsjoch ridge. The organization of the description follows the position of the described structures in the hanging wall and footwall related to the main Karwendel thrust, respectively, and according to the relative age of the structures. We use the cross-cutting relationships between the described structures to deduce a relative age. A relative chronology is also based on the comparison of the shortening/transport directions with other parts of the NCA, where young, syntectonic sediments are present.

\subsection{Karwendel thrust (1)}

The best exposures of the Karwendel thrust are found at Halftergraben (Fig. 4) on the western side of the Gumpenspitze-Gamsjoch ridge. There, Triassic sediments (Reichenhall Fm.) lie on top of Cretaceous deposits (Schrambach Fm.; 1 of Fig. 4), and this old-on-young contact defines the Karwendel thrust and distinguishes it from other tectonic boundaries in the area. The thrust is parallel to bedding in the immediate footwall (above 3 of Fig. 4) and hanging wall, which is close to horizontal on the hectometric scale (see also Fig. $4 c$ and d). In the 


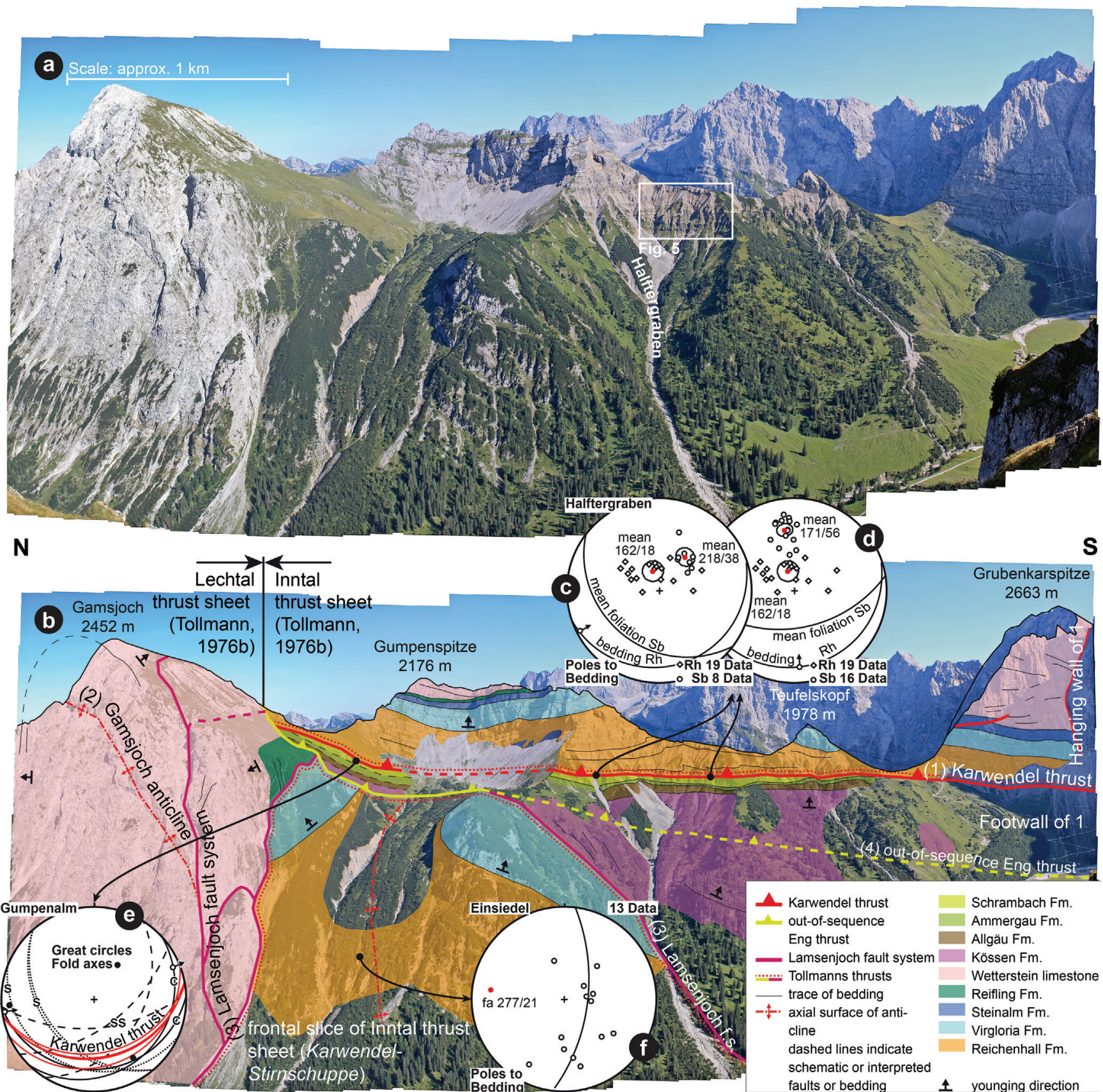

Figure 4: View of the Gamsjoch-Gumpenspitze-Grubenkarspitze ridge from the W. (a) photograph and (b) interpretation and (c) and (d) transport direction across the Karwendel thrust at Halftergraben based on the intersection lineation of the mean orientation of bedding of the Reichenhall Fm. (= Rh) in the hanging wall, which is parallel to the Karwendel thrust, and mean foliation in the Schrambach Fm. $(=\mathrm{Sb})$ of the footwall in two domains. (e) Orientation of the main Karwendel thrust at Gumpenalm (red great circles). Foliation s and shear planes c of two s-c-pairs are given and the transport direction based on the intersection lineation is indicated by arrows on the c-planes. Small-scale fold axes (black circles) are perpendicular to transport directions of (c), (d) and (e). (f) Poles to bedding and fold axis of the Einsiedel anticline. All diagrams in this and the subsequent figures are lower hemisphere equal area stereographic projections, and the TectonicVB software (Ortner et al., 2002) has been used to manipulate and plot the data.

footwall, the zone of deformation reaches approximately $70 \mathrm{~m}$ down into the Allgäu Fm., the most intense deformation being observed in the Schrambach Fm. right below the thrust. In contrast, the complete hanging wall is involved in the deformation.

The emplacement of the allochthon is associated with end-Early Cretaceous nappe stacking postdating the youngest sediments in the area, which is the Schrambach Fm. reaching into the Albian. It is folded in the core of the Gamsjoch anticline and is subvertical in the northern limb, thus disappearing into the subsurface towards the north (Figs. 7 and 10). The Karwendel thrust is offset by the Lamsenjoch fault system (see 4.5; Figs. 7 and 10), and both are cut by the out-of-sequence Eng thrust which causes a doubling within the footwall of the Karwendel thrust (Figs. 4 and 7).

The Karwendel thrust is accompanied by a discontinuous band of rock (Fig. 5) that consists of recrystallized micritic limestone, sparry calcite and stylolites (Fig. 6d). The orientation of the pressure solution seams is (N)NW and 

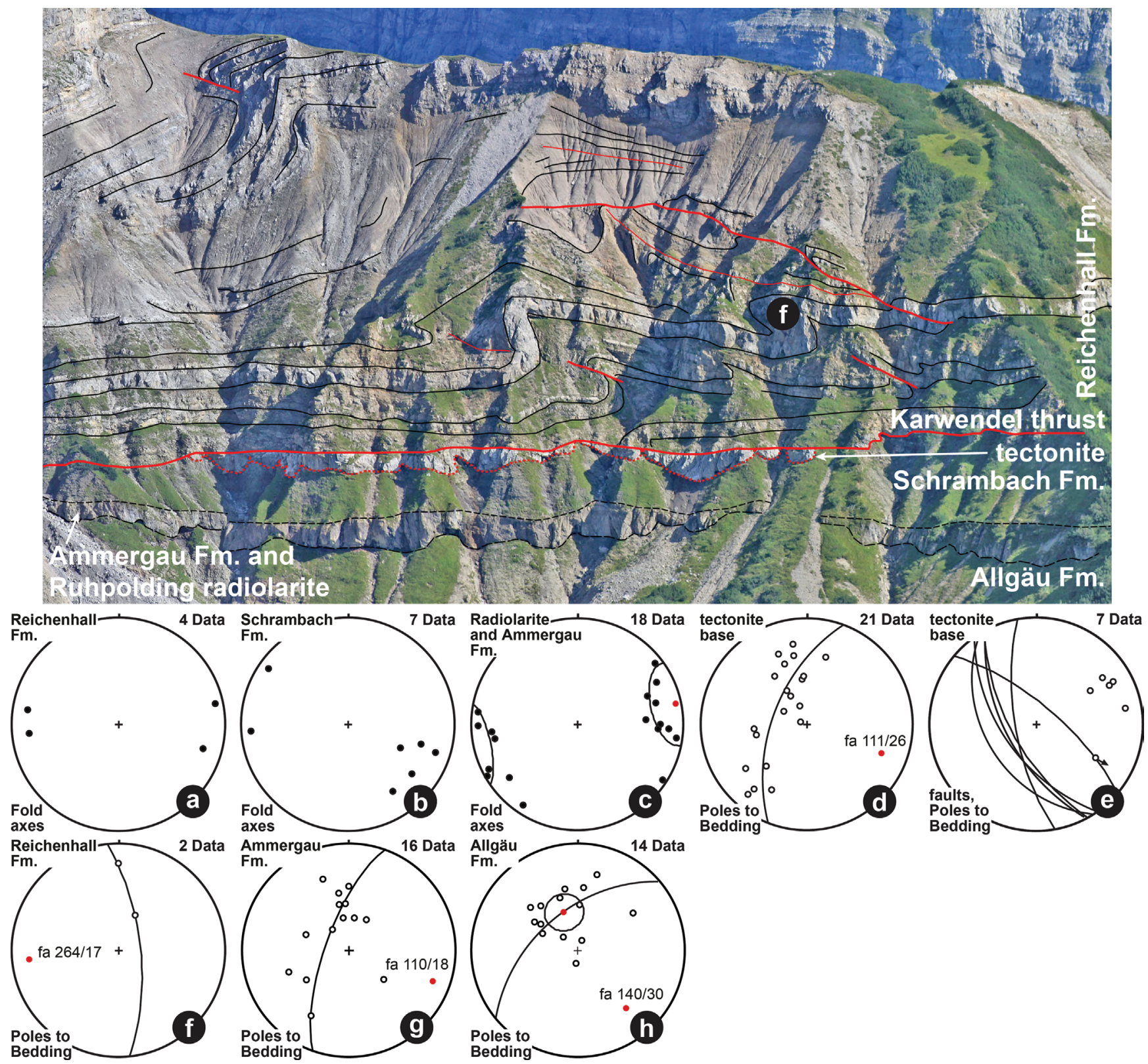

Figure 5: The Karwendel thrust at Halftergraben (see Fig. 4 for location), and structural data collected. (a) Axes of m-scale folds in the Reichenhall Fm., (b) of cm- to dm-scale folds in the Schrambach Fm. and (c) in the Radiolarite and Ammergau Fm. Orientation of the (d) basal surface of the tectonite, and (e) of faults crosscutting the tectonite. (f) Poles to bedding and fold axis of a fold in the Reichenhall Fm. also labelled in the photograph. Poles to bedding in the (g) Ammergau Fm. and in the (h) Allgäu Fm. in the footwall of the Karwendel thrust.

gives evidence of (E)NE-shortening (Z), parallel to the stylolite teeth (Fig. $6 \mathrm{~d}$, top). In a section perpendicular to the thrust and parallel to transport direction (Fig. 6d, bottom), the shortening direction $(Z)$ from stylolithes is parallel to transport direction, and the stretching direction $(\mathrm{X})$ perpendicular to the thrust. We interpret this band of rock as a tectonite, that formed from slices of rock probably derived from the footwall, but that was strongly altered by fluid-rock interaction during progressive deformation. While the top surface of this unit is planar and parallel to bedding of the overlying Reichenhall Fm., the basal surface has a cuspate-lobate geometry on the meter scale, with the Schrambach Fm. protruding into the cusps.

These cusps indicate that the Schrambach Fm. was the weaker unit during transport of thrust sheets. The axes of the cusps trend ESE (Fig. 5d), and are parallel to fold axes in the underlying Schrambach Fm. (Fig. 5b), Ammergau Fm. (Fig. 5g), and roughly parallel to fold axes in the overlying Reichenhall Fm. (Figs. 5a, 7c; see below). Locally, the long axis of the lobes of the tectonite is (sub)parallel to a system of normal faults (Figs. $5 d, e, 6 b$ ). The stretching direction from the faults is parallel to the (E)NE transport direction indicated by the mean bedding-cleavage intersection (Fig. 4c) and transport directions deduced from individual s-c-pairs in the Schrambach (Figs. 4e) and Ammergau Fms. (Fig. 7f), and open folding in the incompetent Allgäu Fm. (Fig. 5h) below the Karwendel thrust (see below). As the normal faults crosscut and offset the lobes of the tectonite, this stretching must be younger than NNE-directed transport that formed the mullion surface. 

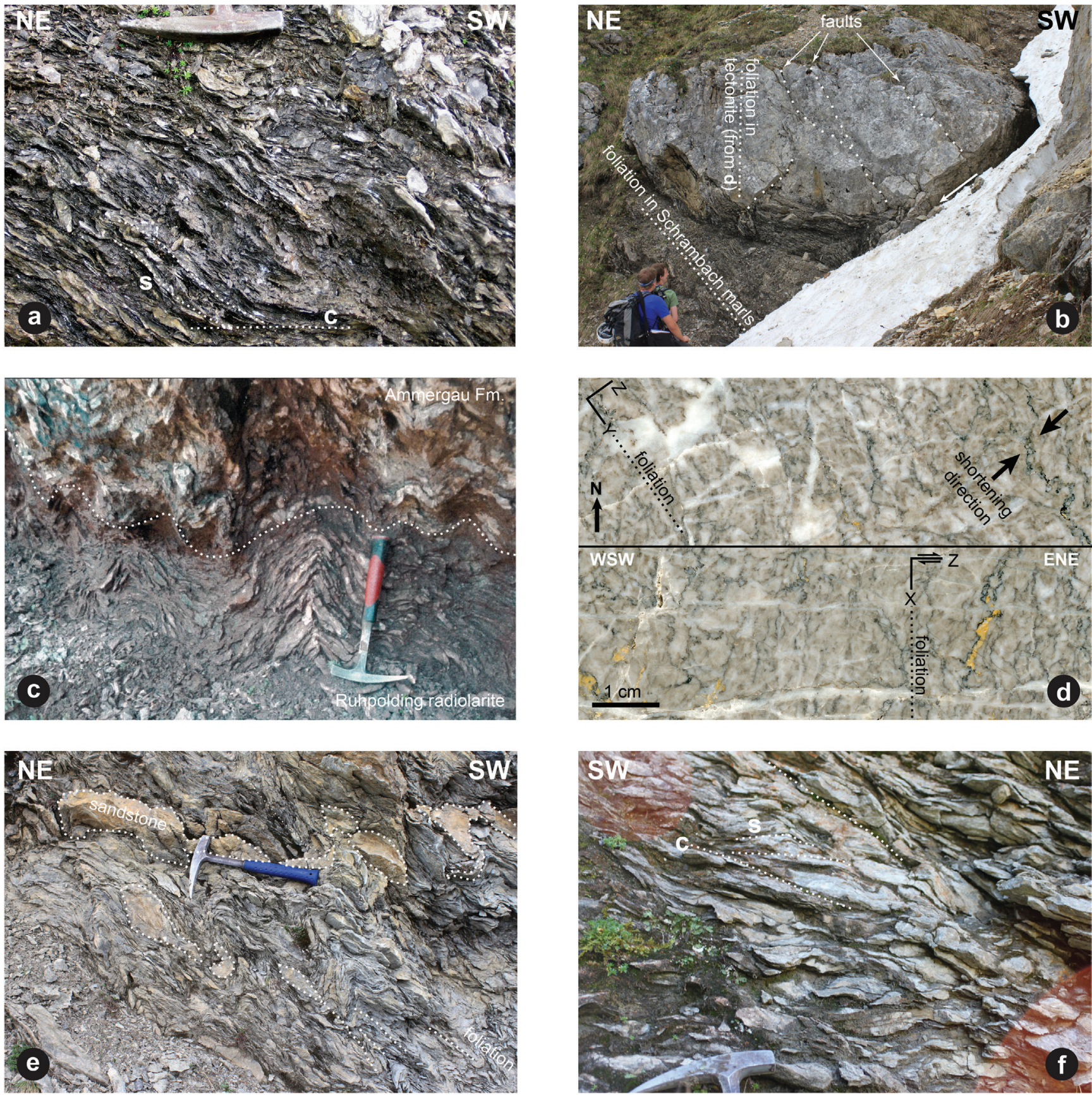

Figure 6: Outcrop-scale structures below the Karwendel thrust. (a) s-c-fabric in the Schrambach Fm. at the location of e in Fig. 4. (b) Second lobe of the tectonite from the south in Fig. 5 in contact to Schrambach Fm. Note the conjugate fault system, N-dipping faults offsetting the tectonite, S-dipping faults not. Arrow indicates hanging wall transport on fault surface. (c) Symmetric folds at the boundary of the Ruhpolding radiolarite to the Ammergau Fm., halfway between the locations of $\mathrm{c}$ and $\mathrm{d}$ in Fig. 4. (d) Oriented polished surfaces of a tectonite sample parallel (top) and perpendicular (bottom) to the Karwendel thrust. Sample location shown by $\mathrm{c}$ in Fig. 4. Note stylolitic foliation perpendicular to, and calcite veins parallel to the direction of shortening (compare Fig. 4c). (e) Foliation and folds within the Schrambach Fm. at the location of $\mathrm{c} \mathrm{in} \mathrm{Fig.} \mathrm{4.} \mathrm{Stippled} \mathrm{line} \mathrm{indicates} \mathrm{sandstone} \mathrm{bed.} \mathrm{Mean}$ bedding parallel to hammer handle. (f) s-c-fabric in the Ammergau Fm. at the location of $f$ in Fig. 7.

It may be related to late transport-parallel stretching as observed in many melange zones (e.g., Biehler, 1990; Jeanbourquin, 1994; Kusky and Bradley, 1999; Needham, 1995).

\subsection{Structure of the footwall}

Below the Karwendel thrust, an upright sedimentary succession from the Hauptdolomit to the Schrambach $\mathrm{Fm}$. is present. The latter is strongly deformed right below the thrust, but deformation features vary in different places. Where the Schrambach Fm. is rich in marly limestone and sandstone, a south to southeast-dipping axial planar foliation is developed (Fig. 6e). Marls have tight $\mathrm{cm}$-scale NE-verging folds (diagram Fig. 5b), whereas sandstones are folded in metric folds. Separation of boudinaged sandstone fragments in overturned fold limbs is partly caused by removal of material during foliation development, but probably also by older boudinage, as 
the distance between fragments is large and cannot be caused by pressure solution alone. Foliation is defined by stylolite surfaces. Across stylolites, parts of $\mathrm{cm}$-scale fold hinges in marls are removed by solution. Where the Schrambach Fm. is rich in marls, and sandstones are missing, s-c-fabrics are found, indicating transport towards the (E)NE (Fig. 6a and f, diagrams of Figs. 4c, e and 7f).

The underlying Ammergau Fm. and Ruhpolding radiolarite are more competent and intensely folded. The top surface of this unit is flat, whereas the lower boundary against the underlying less competent Allgäu Fm. has an irregular metric lobate geometry, and, superposed, the lower half of a decametric pinch-and-swell structure (Fig. 5). Within these boundaries, these units are pervasively folded on the dm-scale (Fig. 6c). These folds are mostly symmetric, only a few verge to the N. Fold axes scatter between SW and WNW, and are distributed along a small circle with an ENE-trending axis (Fig. $5 \mathrm{c}$ ) while poles to bedding plot along a poorly defined girdle about an ESE-trending axis (Fig. $5 \mathrm{~g}$ ).

The small circle distribution of fold axes indicates refolding about an ENE axis (e.g. Ramsay, 1960). A possible sequence of events is initial NW-directed transport, followed by NNW-transport. The poorly defined ESE-fold axis from the Ammergau Fm. bedding poles (Fig. $5 \mathrm{~g}$ ) may be related to still younger NNE-directed transport. On the outcrop scale, the wavy lower boundary of the Ammergau-Radiolarite packet is the only candidate for a superposed folded surface (Fig 5). The contact of this mullion-like surface against the less competent unit below is interpreted as an effect of buckling into the underlying Allgäu Fm. after the dm-scale folds were so tight that the whole Ammergau-Ruhpolding unit started to behave as a homogenous layer developing a new, larger wavelength of buckling.

The sedimentary succession below (Allgäu-, Adnet- and Kössen Fms.) is not affected by pervasive deformation. Isolated, very open, metric folds are present in the Adnetand Allgäu Fms., and only in the latter, recumbent cmto dm-scale slump folds. Poles to bedding in the Allgäu Fm. scatter about the mean orientation of the Karwendel thrust in the area (compare diagrams of Figs. 5h and 4c), but are also folded about a SE-trending axis (Fig. 5h).

East and southeast of the Halftergraben outcrop, the structure immediately below the main thrust is more complex. On the east side of the Gamsjoch-Gumpenspitze ridge, an additional slice repeating the AmmergauSchrambach succession is present (Fig. 7). Further to the south, an isoclinal anticline-syncline pair in the Radiolarite-Ammergau-Schrambach succession are found in the hanging wall of the Eng out-of-sequence thrust (Fig. 10f). The small spread of the bedding poles in this diagram is a consequence of the isoclinal nature of the folds.

\subsection{Structure of the hanging wall}

The sedimentary succession above the Karwendel thrust is not pervasively deformed. Generally, bedding is parallel to the main thrust (Figs. 4, 5). Metric to decametric folds are localized above the cutoff of a bed right against the Karwendel thrust (Fig. 5). Above the cutoff, carbonate beds separated by cellular dolomites are disharmonically folded, the number of folds varies depending on the thickness of the beds. In the bed labelled (f), a fold train of three overturned folds is observed. Wavelength and amplitude of these folds decrease from $\mathrm{N}$ to $\mathrm{S}$. Upsection, the wavelength of the largest of these folds increases to several tens of meters above a thick layer of cellular dolomites while the smaller folds disappear. The syncline at Teufelskopf (Fig. 7c) and the middle fold of the fold train (diagram Fig. 5f) was measured, and verges to the N(NE).

\subsection{Interpretation of mesoscale structures}

Three conclusions can be drawn at this point: (1) The mesoscale structures below the Karwendel thrust can be understood in terms of a shear zone displaying decreasing deformation intensity with increasing distance from the fault core marked by the tectonite. As the incompetent Schrambach and Allgäu Fms. lack structures that can be related to NW-transport, but the more competent Ammergau Fm. and Ruhpolding radiolarite do, we suggest that differences in the rheology of sedimentary units control the preservation of structures. While the more competent units preserve the complete record of polyphase deformation, incompetent units tend to preserve only the youngest events.

(2) In comparison to regional deformation of the Austroalpine and the NCA, Cretaceous, Eoalpine NW-directed shortening was therefore active in the Karwendel mountains but no large-scale folds formed (Fig. 8a). $\mathrm{N}$ - to NNE-directed transport can be related to latest Cretaceous-Paleogene shortening (Eisbacher and Brandner, 1996; Froitzheim et al., 1994; Ortner, 2003b; Oswald et al., 2018), which is also seen within the Penninic nappes underlying the Northern Calcareous Alps (e.g. Biehler, 1990; Ring et al., 1988; Ring et al., 1990). However, a possible contribution of Miocene NE-directed transport can neither be excluded nor proven at this point (see Decker et al., 1994; Ortner, 2003b; Peresson and Decker, 1997).

(3) The hanging wall of the Karwendel thrust does not show evidence of Cretaceous NW-directed shortening, but only of Latest Cretaceous-Paleogene N- to NNE-directed transport.

(4) Shortening was active from the latest Early Cretaceous into the Miocene.

\subsection{Gamsjoch anticline (2)}

The km-scale Gamsjoch anticline folds the hanging wall and the footwall together and is therefore younger than the Karwendel thrust (Figs. 7, 8b). The stratigraphic succession in both fold limbs is comparable, including the old-on-young contact defining the Karwendel thrust (see above), and even the clinoforms in the Wetterstein limestone dip roughly to the south in both limbs (Fig. 7) in their restored geometry. The fold axis plunges to the WNW (Fig. 7d), parallel to the folds above the Karwendel 


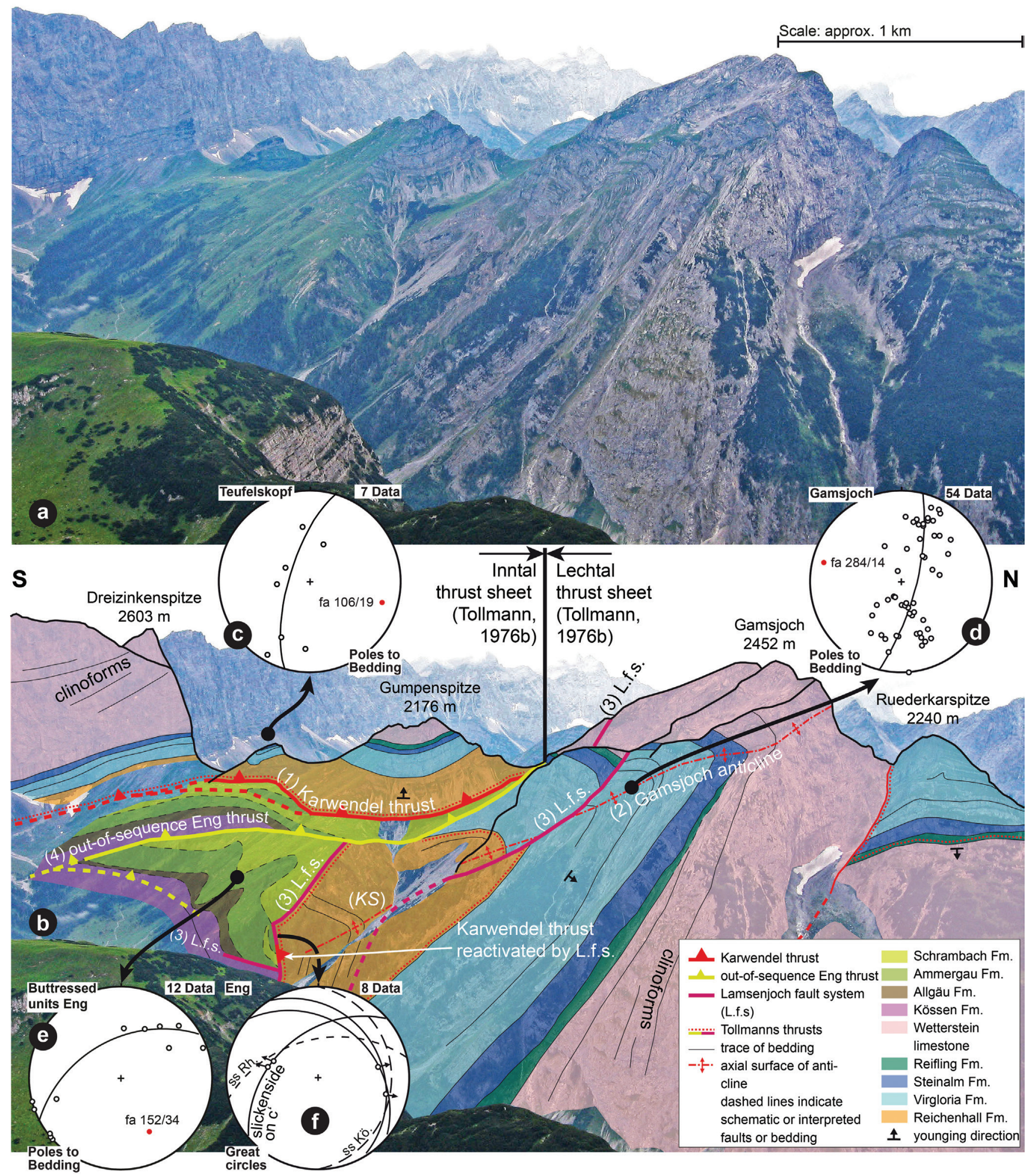

Figure 7: View of the Gamsjoch-Gumpenspitze ridge from the NE. (a) Photograph and (b) interpretation. Poles to bedding and fold axis of the (c) Teufelskopf syncline, (d) Gamsjoch anticline and (e) the buttressed units below the Eng out-of-sequence thrust. (f) Structural data at the reactivated Karwendel thrust: ss Rh. = mean bedding in the Reichenhall Fm. of the hanging wall, ss Kö. = mean bedding of the Kössen Fm. in the undeformed footwall. $\mathrm{s}, \mathrm{c}=$ foliation and shear planes in s-c-fabrics in the Schrambach and Ammergau Fms, $\mathrm{fa}=$ fold axis. Arrows indicate hanging wall movement on shear planes below the Karwendel thrust, KS = frontal slice of the Inntal thrust sheet (Karwendel-Stirnschuppe) of Tollmann (1970), L.f.s. = Lamsenjoch fault system.

thrust (see above). On larger scale geologic maps (e.g. Fig. 2), these folds are truncated by the northern branches of the Miocene Inntal shear zone (Ortner, 2003b; Ortner et al., 2006; Ortner and Stingl, 2001); thus, a Paleogene age is more likely for these folds. Latest CretaceousPaleogene folding thus caused the Karwendel thrust to lock (Fig. 8b) and to disappear in the subsurface towards the north (see paragraph 4 in chapter 5.4). 
emplacement of upper thrust sheet

$\mathrm{S}$

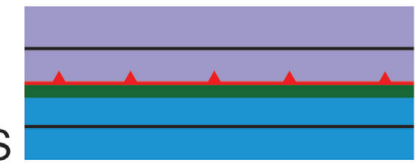

a end Albian
Gamsjoch anticline folding

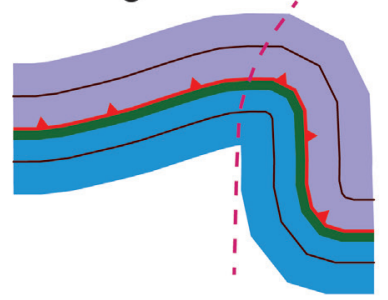

(b) Early Paleogene
Lamsenjoch fault

system

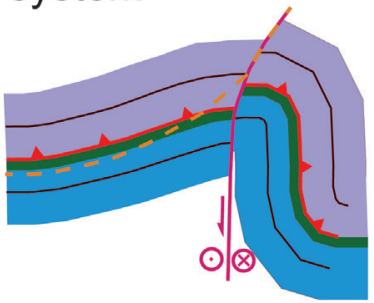

C Late Paleogene out-of-sequence

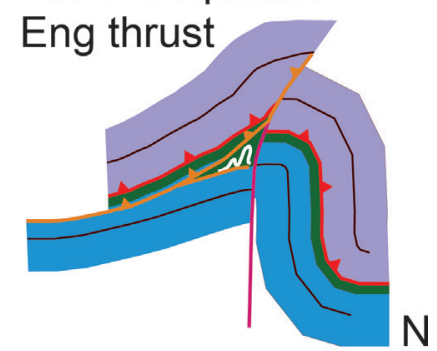

d Latest Paleogene

Figure 8: Kinematic evolution of the cross section in the area of the Gamsjoch anticline. See text for discussion.

The Gamsjoch anticline is part of a larger anticline that extends to the Eiskarspitze (Fig. 11). This fold formed during NNE-directed shortening, as most of the other km-scale folds of the Karwendel mountains (Heißel, 1978; Tollmann, 1976b). Folding the nappe stack lead to a regional uplift of anticlines, later out-of-sequence thrusting caused the today's structural situation (Fig.12).

\subsection{Lamsenjoch fault system (3)}

The subvertical WNW-striking Lamsenjoch fault runs across the uppermost Falzthurn valley (label FT of Fig. 2) and the Eng valley cuts the Gamsjoch anticline (Figs. 4, 7 and 14) and then continues further west. In the western flank of the ridge between Gumpenspitze and the Gamsjoch, this strike-slip fault system cuts across the axial plane of the Gamsjoch anticline (Fig. 4). The upward diverging nature of the faults in Fig. 4 suggests the geometry of a flower structure. Across single-fault branches, the southern block is systematically downthrown (e.g. fault south of Gamsjoch summit of Fig. 7). This is less obvious in other views. In Fig. 4, the steep, overturned limb of the Gamsjoch anticline is offset against the upright limb across the northernmost fault branch, and an upright limb is in contact with the overturned limb across the next fault branch. In Fig. 10, the overturned limb of the eastern continuation of the Gamsjoch anticline is in contact with the upright limb across the northernmost branch of the Lamsenjoch fault. There, major normal offset is required, as the upright limb is south of the closure of the syncline, and this limb can only come from above.

The direct contact of the upright Kössen Fm. of the Lechtal thrust sheet and the overturned Reichenhall Fm. of the Inntal thrust sheet across the southern branch of the Lamsenjoch fault system (Fig. 11) is more difficult to explain. Obviously, the fault cuts out the core of the anticline by lateral movements. This branch of the fault reactivated the folded, pre-existing Karwendel thrust, where it is subvertical to north-dipping in the deeper part. The upper part is parallel to the axial plane of the Gamsjoch and was probably guided by bedding-perpendicular pre-existing fractures. In summary, a combination of lateral and south-block down normal offsets is required to explain the observed contacts in the area. Another indication of lateral offset is the different thickness of sedimentary units in the Muschelkalk Group, for example, the
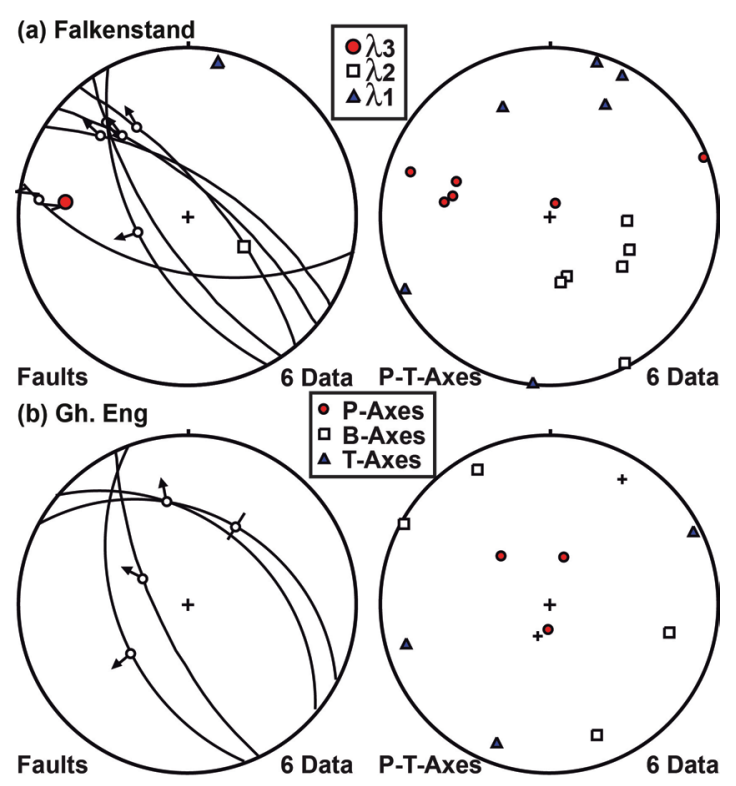

Figure 9: Brittle faults collected at (a) Falkenstand (see Fig. 2 for location) and near Gh. Eng (see Fig. 10 for location), and the respective kinematic axes. The fault data document sinistral transtension comparable to the data set of Fig. 10d and e.

Virgloria Fm. being $50 \mathrm{~m}$ thick $\mathrm{S}$ of the fault and $400 \mathrm{~m} \mathrm{~N}$ of it (Fig. 11). Unfortunately, no clear cutoffs are present to quantify offset.

Brittle fault data were collected in the Falzthurn valley (diagrams d and e of Fig. 10; for location see label FT of Fig. 2). The girdle distribution of the $P$ - and $B$-axes and the shape factor of $R=0,75$ of the incremental strain ellipsoid from inversion of the fault data using the NDA method (Spang, 1972) give evidence for sinistral transtension along WNW-striking faults. The fault data sets also contain dip-slip and oblique-slip normal faults, suggesting that faults with a relative normal offset and moderate dip (Figs. 4, 10) are also part of this fault system. Fault data collected at Falkenstand west of the Gamsjoch (label FS of Fig. 2) and around Gh. Eng of Fig. 10 shows the same general fault pattern (Fig. 9).

The WNW striking sinistral transtensive Lamsenjoch fault system is younger than the Karwendel thrust and younger than the Gamsjoch anticline because it offsets the thrust and runs into bedding in the steep limb of the fold. We interpret the normal, south-block down faults of the study area as branches of the Lamsenjoch fault 


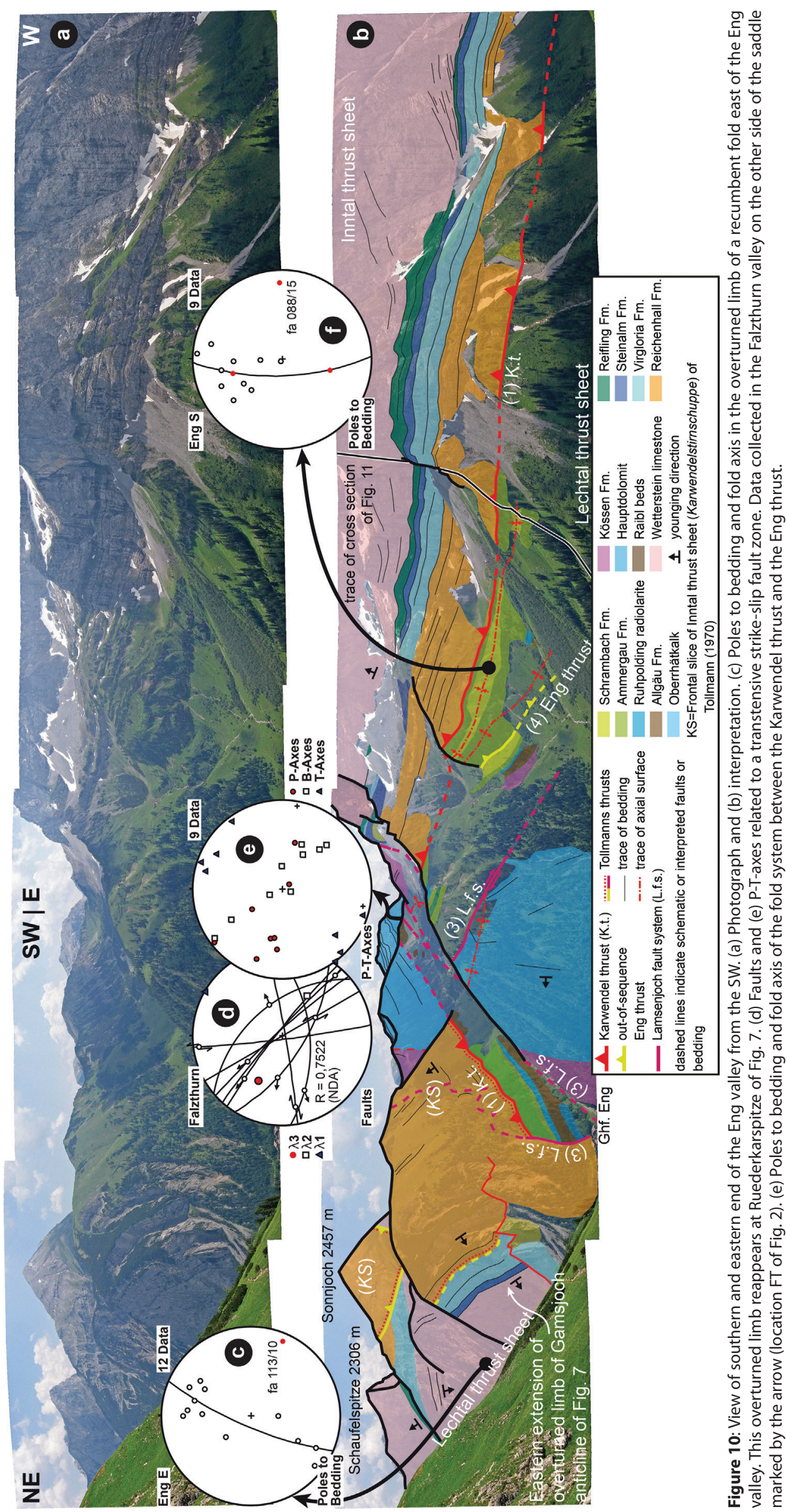




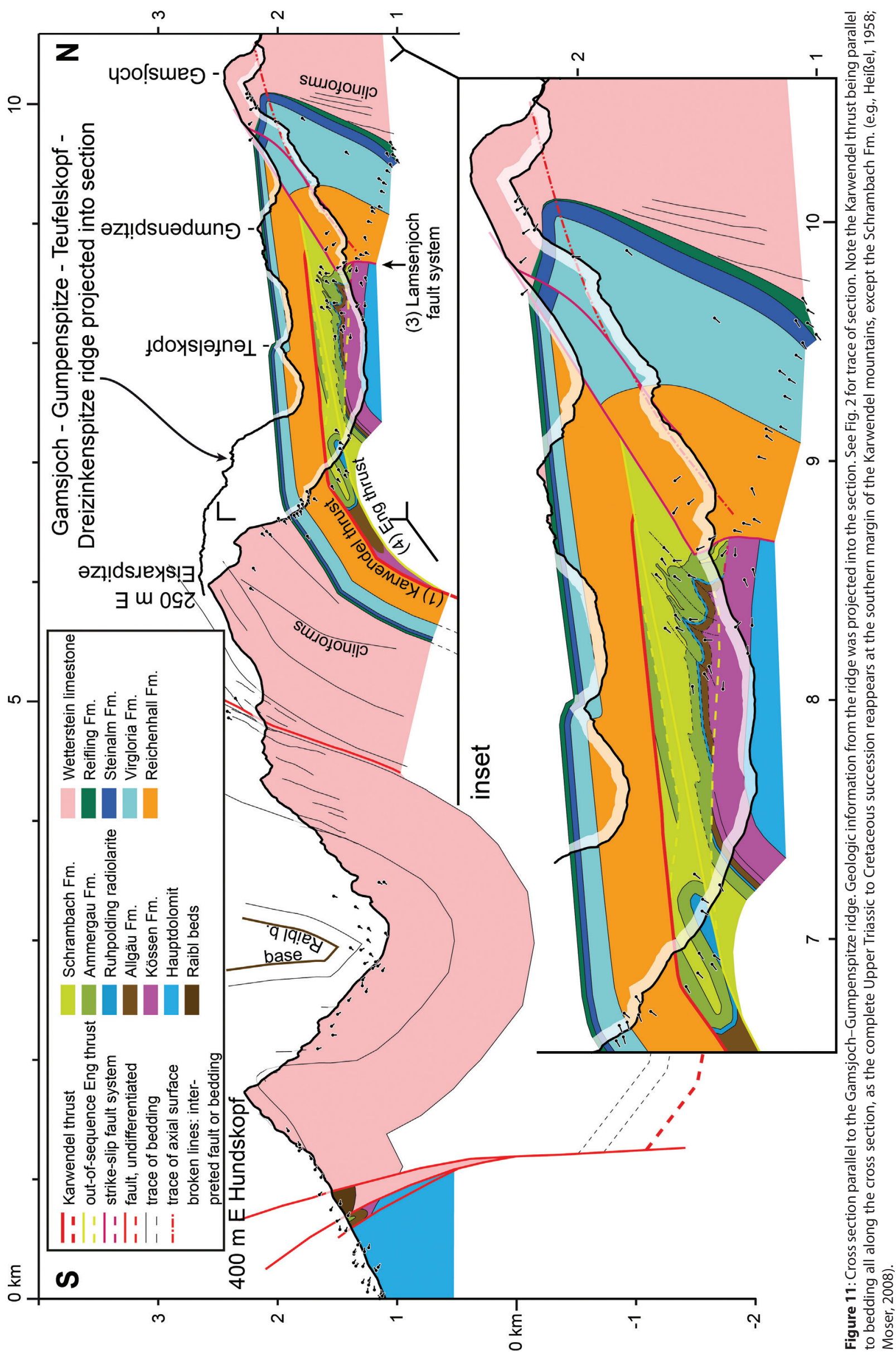


system. The structural relations (Figs. 4, 7, 11) showed that these faults were active in post- or latest Paleogene times (post-Gamsjoch anticline), probably Oligocene. Transtensive brittle faulting at sinistral WNW-trending master faults conjugate with ESE-trending faults (Figs. $10 d, 9)$ has not been recorded previously. In older studies, dextral faulting across NW to WNW-trending tear faults has been associated with dextral tear faulting related to Cretaceous transport of thrust sheets (Eisbacher and Brandner, 1995; 1996). Sinistral reactivation of these has been attributed to Late Miocene E-W compression in other parts of the NCA (Ortner, 2003b; Peresson and Decker, 1997) and is not comparable to the observed Oligocene transtensive faulting.

\subsection{Out-of-sequence Eng thrust (4)}

The Eng thrust crosscuts the Karwendel thrust and doubles the Upper Triassic to Lower Cretaceous succession of the Lechtal thrust sheet. Towards the north, this Eng thrust merges with and reactivates the southern branch of the Lamsenjoch fault system in Figs. 7 and 11, which crosscuts the Gamsjoch anticline. Therefore, the Eng thrust is youngest structure in the area, and out-ofsequence with respect to folding and stacking of thrust sheets. The Upper Triassic to Lower Cretaceous succession in the footwall of the Eng thrust is detached at the Kössen marls and buttressed against the Lamsenjoch fault, causing open to isoclinal folding within the Allgäu-, Ammergau and Schrambach Fms. with an axial planar foliation subparallel to the Lamsenjoch fault (inset of Fig. 11). Folding thickens and moves the buttressed units up the upper, south-dipping part of the Lamsenjoch fault, thus emplacing units belonging to the Lechtal thrust sheet onto the tectonically higher Inntal thrust sheet (Figs. 7 and 11 ; Fig. $8 \mathrm{~d}$ ).

This process is even more pronounced at the western side of the Gamsjoch-Gumpenspitze ridge, where the Eng thrust emplaces the Upper Triassic to Lower Cretaceous rocks in its hanging wall onto an upright folded slice of Reichenhall-Virgloria Fm. and truncates the crest of the fold (Fig. 4). There, s-c-fabrics in the Schrambach Fm. give a NE transport direction (Fig. 4e).

Buttressing in the footwall of the Eng thrust caused stacking and tilting of several slices within the Kössen $\mathrm{Fm}$. against a southern branch of the Lamsenjoch fault system (Fig. 4).

(E)NE-directed transport related to activity of the Eng thrust also overprints the incompetent units and the tectonite in its hanging wall that are sandwiched between the Eng and the Karwendel thrusts (Figs. 4c, e, Fig. 7), and the folded units detached from the competent Hauptdolomit below the Eng thrust (Fig. 7e). It reactivates the Karwendel thrust, probably not causing large offsets.

The out-of-sequence Eng thrust is the youngest event in the study areas because it truncates all other structures. From structural data (see above), we suggest the transport across the out-of-sequence thrust was (E)NE directed. The age of the out-of-sequence Eng thrust must be younger than the Gamsjoch anticline and the steep faults, and is probably Latest Oligocene to Miocene. Such an age is in accordance to observations in the Inn valley, where soft-sediment folding with NW-axes has been observed in Upper Oligocene deposits (Ortner, 2003b; Ortner and Stingl, 2001). However, also Miocene age $\mathrm{NE}$-compression has been documented, which is mostly strike-slip but also thrust-type (Decker et al., 1994; Ortner, 2003b; Peresson and Decker, 1997).

\section{Discussion}

\subsection{Timing of the structures observed}

In summary, shortening from the late Early Cretaceous onward has been observed, roughly following the changing plate convergence direction changing from NW directed to NE directed (e.g. Dewey et al., 1989) while the Oligocene to Miocene/shortening direction is controlled by escape tectonics that creates secondary stress fields (Decker et al., 1994; Ortner, 2003b). On the local scale, the kinematic history as deduced from the observations starts with Eoalpine, end-Albian NW-directed stacking of thrust sheets. Transport and shortening continued into the Paleogene and changed to $\mathrm{N}$ directed and $\mathrm{NE}$ directed. In a late stage of this process, the first, kmscale, WNW-trending folds of the Karwendel mountains formed (Fig. 2), including the Gamsjoch anticline, that refolds the thrust boundary, which disappears into the subsurface. Folding locked the thrust boundary. Shortening was interrupted by Late Oligocene sinistral transtensive shearing at WNW-trending faults, which separates NE-directed Early Paleogene from (E)NE-directed Late Paleogene-Neogene transport, and initiated out-of-sequence thrusting. In the following, we discuss some of the kinematic-mechanical boundary conditions of thrusting and out-of-sequence thrusting.

\subsection{Kinematic evolution, salt tectonics and fluid overpressure}

The difference in the kinematic histories recorded in the footwall and the hanging wall of the Karwendel thrust is conspicuous. While the full kinematic history is documented in the footwall, only (Paleogene) NNE transport is seen in the hanging wall. Part of the explanation might be the presence of rock salt at the Karwendel thrust (see section 3.1), decoupling the hanging wall during a part of the kinematic history. However, in this case, neither the footwall nor the hanging wall should show a kinematic record. The solution of the problem may be the fact that the salt pillows of the Haselgebirge had a limited lateral extent (e.g. Leitner and Spötl, 2017; Spötl, 1988), and the salt is mobile and migrates laterally or upward (e.g. Hudec and Jackson, 2007; Jackson and Hudec, 2017). Therefore, the Karwendel thrust had to cut from the base to the top of the NCA sedimentary succession across a ramp, and to emplace the Inntal thrust sheet on the upper flat, until the salt reached the position of the present-day Karwendel mountains. During 
this part of the history, the frontal parts of the Inntal thrust sheet would pass the footwall presently exposed in the Karwendel mountains and record the kinematic history. A trailing part of the Inntal thrust sheet floored by salt would have been entirely decoupled from the footwall during transport and not record this kinematic history. This is in line with the observation that there was no large-scale folding associated with early, Eoalpine transport. Only after flow of salt out of the thrust zone, the thrust sheet grounded, and mechanical coupling was possible, and both hanging wall and footwall were affected by Early Paleogene deformation. Salt expulsion probably also contributed to strengthening of the thrust itself, and forced the décollement to move out of the Schrambach-Reichenhall contact into marls of the Kössen Fm. below.

Fluid overpressure at the thrust contact would have comparable effects, and the release of overpressure would leave only minor traces in the rock record (e.g. Dielforder, 2017; Dielforder et al., 2015). Finite strain in the tectonite immediately below the Karwendel thrust, with the long axis $X$ perpendicular to and the short axis $Z$ parallel to the thrust and ENE trending (Fig. $6 \mathrm{~b}$, d), documents pure shear deformation, whereas simple shear is observed in the underlying foliated Schrambach marls (Fig. 6a, b, e). The absence of simple shear in the tectonite requires full decoupling and strain partitioning, which was probably achieved by near-lithostatic fluid pressures (compare, e.g., Tobin et al., 1994). This interpretation is in accordance with the outcrop-scale geometry of the tectonite. The cuspate-lobate interface between the tectonite and the Schrambach Fm. requires shortening parallel to the thrust, whereas the planar top surface against the Reichenhall Fm. requires mechanical decoupling to facilitate transport of the hanging wall with low friction, thus not disturbing the tectonite. The orientation of the foliation in the tectonite and underlying Schrambach-Fm. points to Late Paleogene-Miocene formation of foliations and existence of overpressure, and therefore this event is distinct from the earlier, Cretaceous-Early Paleogene history (see above) in terms of orientations and mechanics.

\subsection{Tectonic subdivision of the NCA in the study area}

Here, we discuss the thrust sheet boundaries as defined by previous authors in the light of our analysis. As outlined in the introduction, many problems arise from the fact that the simple criterion that thrusts emplace old on young rocks has not been applied systematically. In his discussion of the thrust sheet boundaries of the NCA, Heißel (1958, page 124) stated, "Es kann auch keine Bedingung für den Begriff einer Decke sein, daß sie überall mit Älterem auf Jüngerem liegt" (It cannot be a requirement for a nappe to emplace old on young rocks everywhere). This argument has been used to interpret all sorts of boundaries as thrust sheet boundaries.

For illustration, the boundary of the Inntal against the Lechtal thrust sheet as shown in the maps of Tollmann (1976b) has been marked by a red stippled line in the hanging wall (= Inntal thrust sheet) of the respective boundaries in the panoramic views of the studied area (Figs. 4, 7, 10). While the uppermost thrust is straightforward and fits all definitions of a thrust, the other boundaries are problematic. In Fig. 4, the frontal slice of the Inntal thrust sheet is a fault block between two branches of the Lamsenjoch fault system, which is also truncated by the Eng out-of-sequence thrust at the top. In Fig. 7, the southern boundary of this slice is the main branch Lamsenjoch fault system while the stratigraphic contact between the Virgloria and Reichenhall Fms. in the core of the Gamsjoch anticline forms the northern boundary. In Fig. 10, this frontal slice of the Inntal thrust sheet is bounded to the south by a segment of the Karwendel thrust, but the northern boundary is an out-of-sequence thrust that develops from bedding-parallel shear in the completely overturned limb of a recumbent syncline. Based on the ESE trend of the fold axis (Fig. 10c), refolding of the overturned limb took place in the Early Paleogene. This thrust is not folded and therefore younger, and is related to Latest Paleogene to Miocene out-of-sequence thrusting, comparable to the Eng out-of-sequence thrust (see above).

The Gamsjoch-Gumpenspitze ridge has been regarded to be a key area for the understanding of the tectonic subdivision of NCA in the past. The folding of the Karwendel thrust in the core of the Gamsjoch anticline has not been recognized previously (see cross sections in Ampferer, 1902; 1928; Richter, 1929), except Brandner (2014), probably because of the overprinting by the Lamsenjoch fault system and by the Eng out-of-sequence thrust. Ampferer (1928) tried to explain the observed multiphase cross section geometry by a single tectonic event and claimed that a thrust onto an existing surface relief (his "Reliefüberschiebung") could explain the observations. At the same time, Richter (1929) connected the Karwendel thrust and the southern branch of the Lamsenjoch fault system in a sketch of the western side of the Gamsjoch-Gumpenspitze ridge (the view of Fig. 4) and concluded correctly that the two summits should be in the same tectonic unit, based on faulty arguments. Looking at the cross sections with today's background, these are not admissible (e.g. Dahlstrom, 1969). Based on his schematic sketches, the "Reliefüberschiebung" of Ampferer (1928) would correspond to a break-through or out-of-sequence thrust cutting across pre-deformed units. A thrust emplacing its hanging wall onto a land surface like, for example, the present-day eastern frontal thrust of the Andes (e.g. Costa et al., 2000; Schmidt et al., 2011; Vergés et al., 2007) is not at all comparable to the thrusts of the Karwendel mountains, mainly because of the absence of syntectonic continental deposits in the footwall.

The geometry of the Karwendel thrust in Figs. 7 and 11, disappearing into the subsurface in the northern limb of the Gamsjoch anticline, shows that the thrust must continue to the north below the Karwendel 
syncline (Fig. 1), and the Inntal and Lechtal thrust sheets are connected. This observation is not isolated, and the connection has also been documented in the Wetterstein and Mieming mountains further west (see Fig. 1; Ortner and Bitterlich, 2016; Schlagintweit, 1912a). The thrust reappears at the northern margin of the NCA (Figs. 1 and 12), where the youngest sediments on top of the Allgäu thrust sheet are uppermost Albian in age W of Oberammergau (Gaupp, 1982; Höfle et al., 1969) and on the trace of the cross section of Fig. 12 (Doben et al., 1991). This increases the amount of transport of the upper onto the lower thrust sheet to a minimum of $38 \mathrm{~km}$ which is the horizontal N-S distance between the southern and northern margin of the upper thrust sheet. The estimate disregards folds, minor thrusts, and the changing transport direction through time (see above). However, using any other transport direction would increase the estimate.

How to define a thrust sheet? An important argument is geometric relationships, as discussed in chapter 5.1. A second argument is the time of emplacement, which is given by the age of the youngest sediments below the thrust (Figs. 1 and 12; Mandl et al., 2017; Ortner, 2003a). Using this argument, the eastern Inntal- and the Lechtal thrust sheet were emplaced at the same time. In combination with geometry (see above), only two large thrust sheets are left on the NCA, the deeper one corresponding to the Allgäu thrust sheet in the north and the Lechtal thrust sheet in the eastern Karwendel mountains, the upper including the main body of the Lechtal- and the Inntal thrust sheets (Figs. 2 and 12a). To avoid confusion of different nomenclatures, we name the tectonically deeper thrust sheet the Tannheim thrust sheet, as the largest area exposing this thrust sheet is the Tannheim valley ENE of Oberstdorf (Fig. 1), and the upper thrust sheet the Karwendel thrust sheet, which has the best exposures of its lower boundary in the Karwendel mountains (Figs. 4, 5). We show this new subdivision in Fig. 13, for a preview of this new subdivision on the scale of the western NCA, see Fig. 24 in Ortner (2016).

It is not useful to separate thrust sheets along local out-of-sequence thrusts such as the Eng thrust (Figs. 4 and 7), as this obscures the older, in-sequence history of the Karwendel thrust. However, these thrusts are still tectonic boundaries and can have considerable offset. In Fig. 13, transport of klippen of the Tannheim thrust sheet onto the Karwendel thrust sheet is at least $3 \mathrm{~km}$, but still only a tenth of the transport of the Karwendel thrust sheet. Separating a thrust sheet in the hanging wall of the Eng thrust would mean to include the Inntal thrust sheet of Tollmann (1976b) and the upper part of his Lechtal thrust sheet in a tectonic unit detached during the Late Paleogene-Miocene. This is in contrast
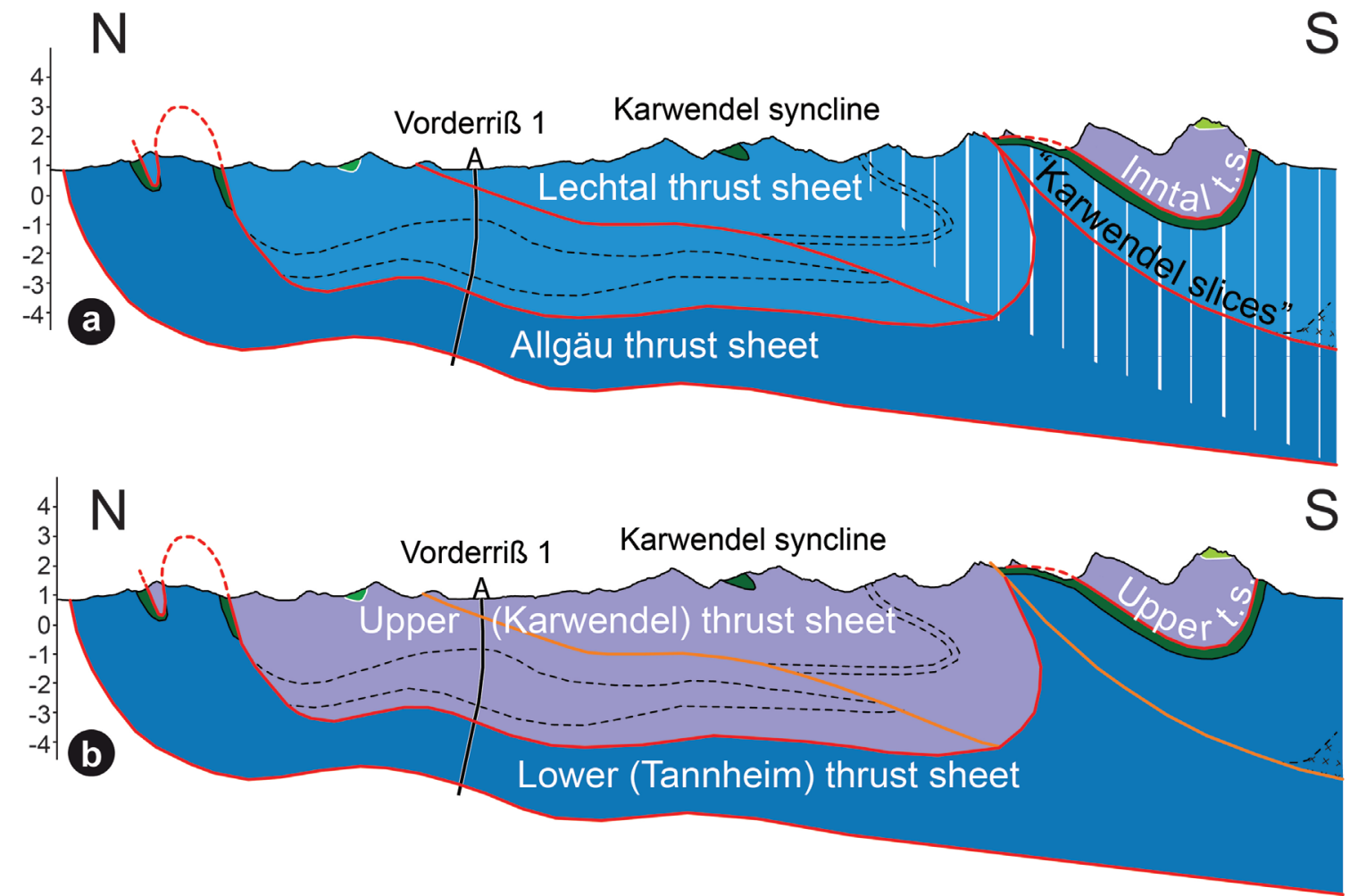

Figure 12: Conceptual N-S cross sections of the NCA illustrating (a) the tectonic subdivision of Tollmann (1976b), and (b) the tectonic subdivision suggested in this paper. White vertical hatch in (a) shows the extent of the Karwendel zone of slices as proposed by Heißel (1978). Dashed black line indicates the Raibl beds. Deep structure based on the cross section of Bachmann and Müller (1981) across the well Vorderriß 1, projected 7 km from the W. The segment of the cross section between the Vorderriß well and the Karwendel syncline based on enclosure 6 in Freudenberger and Schwerd (1996). See Fig. 1 for trace of section and colour code of (a), and Fig. 13 for colour code of (b). Note Albian age synorogenic sediments both below the Lechtal- and Inntal thrust sheets of (a), justifying the merge of the Inntal- and Lechtal thrust sheets into the Karwendel thrust sheet of (b). In this context, the Karwendel zone of slices appears to be a zone of out-of-sequence duplexing uplifting the southern part of the Karwendel thrust sheet. See Reiter et al. (2018) for a more elaborated cross section nearby. 
to the concept of Eoalpine, Cretaceous nappe stacking in the NCA.

The thrust sheets of the NCA have traditionally been arranged in groups or nappe systems, based on their paleogeographic position on the Triassic Eurasian continental margin (e.g. Haas et al., 1995; Lein, 1987). As transport of thrust sheets was directed towards the continent, the tectonic position correlates with their paleogeographic origin. Therefore, the most oceannear parts of the continental margin are represented by the tectonically highest Juvavic group of thrust sheets, the units near the shelf break by the Tirolic thrust sheets occupy an intermediate tectonic position, and the continent-near Bajuvaric thrust sheets are the tectonically deepest units (Mandl, 2000; Pestal et al., 2009; Tollmann, 1976b). Within this system, the Allgäu and Lechtal thrust sheets were regarded to be part of the Bajuvaric units, whereas the Inntal thrust sheet belongs to the Tirolic units (Mandl, 2000; Schmid et al., 2004; Tollmann, 1976b). Merging the Inntal and Lechtal thrust sheets into the Karwendel thrust sheet creates the problem to which larger unit it belongs. Within the sedimentary succession of the Tirolic thrust sheets, two sedimentary units are characteristic: the Upper Jurassic Oberalm Fm. that contains allodapic limestones (Flügel and Fenninger, 1966; Steiger, 1981; Tollmann, 1976a) and the Lower Cretaceous Roßfeld Fm. (Decker et al., 1987; Faupl and Tollmann, 1979) that are both absent in the Bajuvaric thrust sheets. The Jurassic and Cretaceous sedimentary succession in the Karwendel and the easterly adjacent Thiersee synclines (Figs. 1) in the Karwendel thrust sheet includes both the Oberalm Fm. (Nagel et al., 1976; Ortner and Kilian, 2016), and up to $150 \mathrm{~m}$ thick Lower Cretaceous, Aptian-Albian sandstones in the eastern Thiersee syncline (Wilmers, 1971) comparable to the Roßfeld Fm. Therefore, the Karwendel thrust sheet belongs to the Tirolic thrust sheets (compare Mandl et al., 2017).

\section{Conclusion}

The structural analysis of the Karwendel thrust in the Gamsjoch-Gumpenspitze ridge of the eastern Karwendel mountains, that is a key outcrop in the discussion of the tectonic subdivision of the NCA, resulted in the

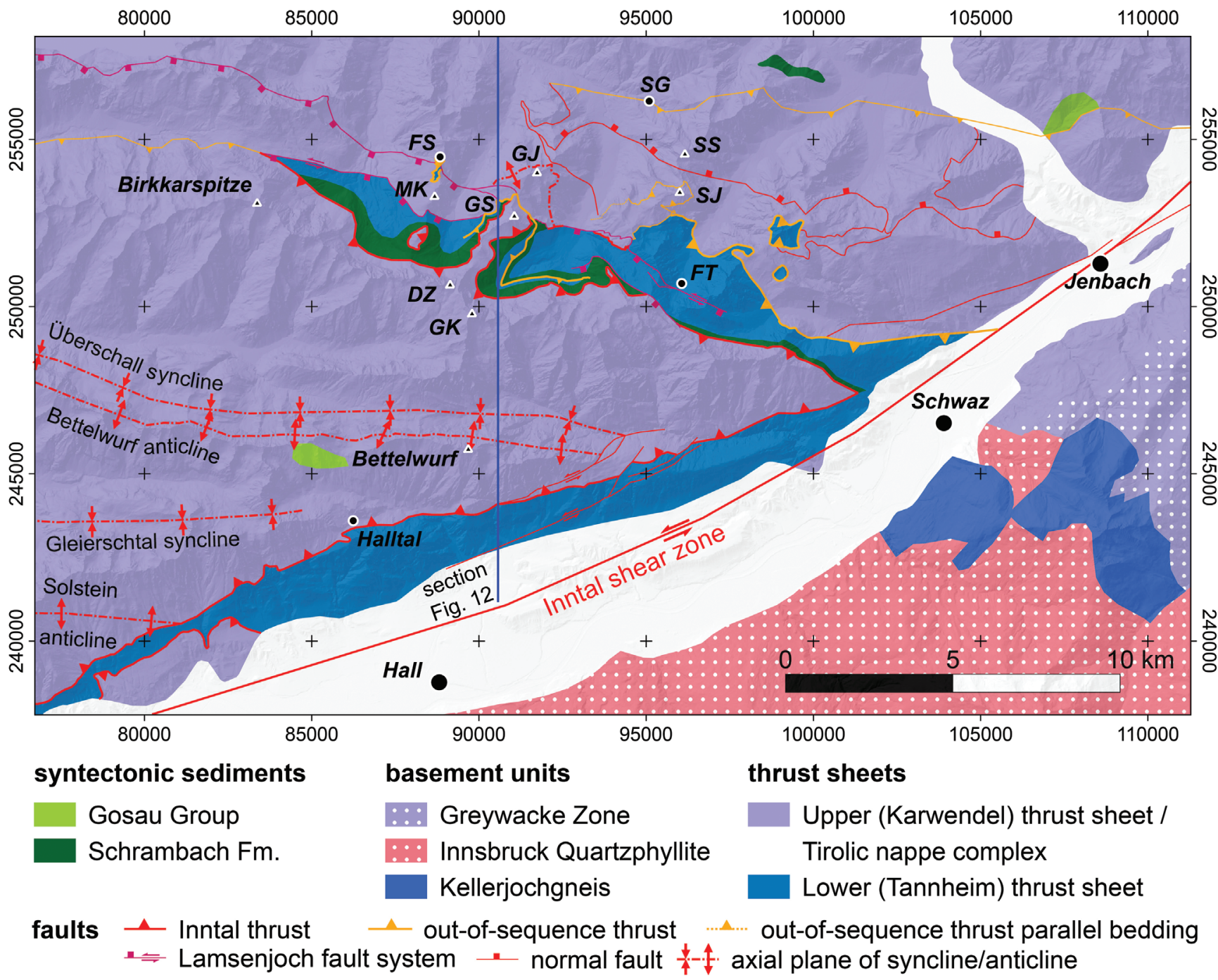

Figure 13: Tectonic map of the studied area distinguishing in-sequence thrusts (Karwendel thrust) and out-of-sequence thrusts (e.g. Eng thrust). The latter locally superimpose younger on older rocks, and are frequently not parallel to bedding. For explanation of abbreviations, see Fig. 2. 
proposal of a new tectonic subdivision. As the Karwendel thrust is seen to be folded in the core of the anticline, it continues to the $\mathrm{N}$ below the Karwendel syncline, and the Inntal- and Lechtal thrust sheets must be part of a larger tectonic unit that has been termed the Karwendel thrust sheet here (Fig. 12). For the same reason, the former Allgäu thrust sheet increases in size as well and now includes the former Lechtal thrust sheet of the eastern Karwendel mountains in the new Tannheim thrust sheet. The Karwendel thrust sheet was emplaced at the end of the Albian, based on the age of the youngest synorogenic sediments on top of the Tannheim thrust sheet (Fig. 12).

The failure to recognize the folded thrust has its reason in the multiphase overprinting of the initial thrust boundary (Fig. 8). Post-emplacement strike-slip faults offset the thrust and forced it to climb across a vertical step, causing initial buttressing against the fault in the footwall of an out-of-sequence thrust, and then emplacement of young on old rocks (Fig. 8). The recognition and differentiation of in-sequence versus out-of-sequence thrusts is of fundamental importance when resolving the structural history of an area and depends on the strict application of the rule that initial stacking emplaces old on young rocks. Here, we demonstrate that out-of-sequence thrusts may emplace klippen and halfklippen as well, but the structural context is different from in-sequence thrusts, as these locally emplace young on old rocks, and crosscut pre-existing structures.

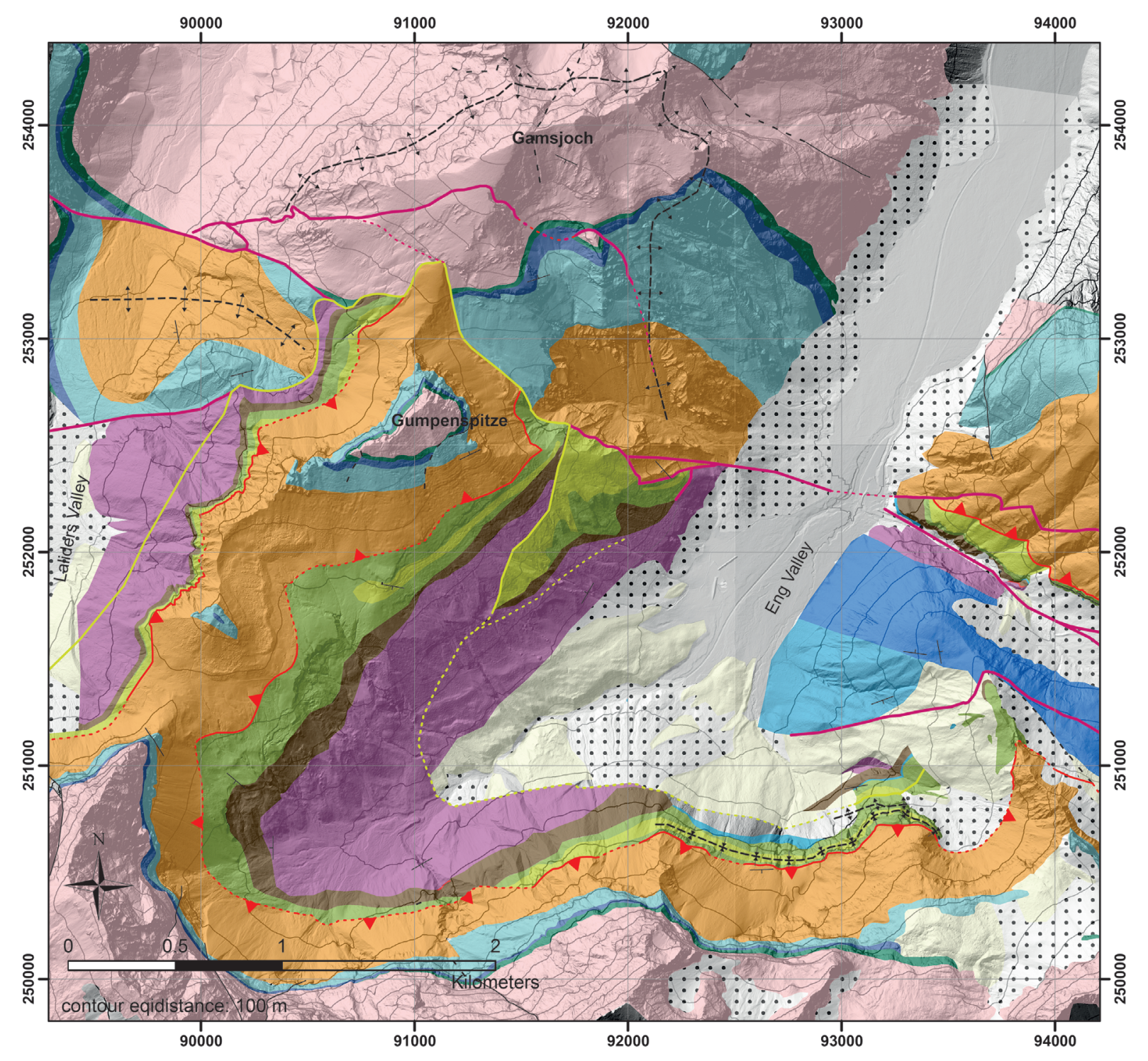

Faults

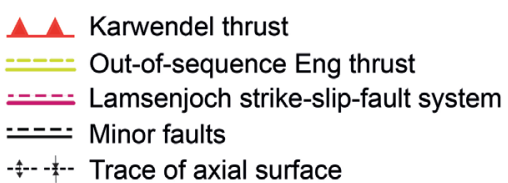

\section{Stratigraphy}

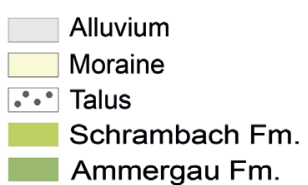

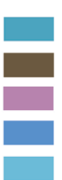

A
Allgäu- and Adnet Fm. Kössen Fm

Plattenkalk Hauptdolomit

Figure 14: Geologic map of the study area. Graticule: MGI Austria GK West. 
The analysis demonstrated that shearing across the thrust sheet boundary continued from the Cretaceous into the Miocene. Regarding the structural record, Early Paleogene $\mathrm{N}$ to NNE-directed transport produced the most pervasive structures, even if transport was mostly accomplished during the Cretaceous. However, also Latest Paleogene-Miocene transport left a structural imprint on the thrust, even if transport was small.

\section{Acknowledgements}

We thank Midland Valley who provided their Move software that was used to construct the cross sections in figures 8, 11 and 12 in the frame of their academic software initiative. The work of Sinah Kilian was supported by the Geologic Survey of Austria and a scholarship of the University of Innsbruck. We thank Alfred Gruber for help during fieldwork and many lengthy discussions. Some of the structural data and the photograph of Figure $6 c$ were collected by Kajetan Heigert in the course of preparation of his bachelor thesis in the Halftergraben. Some of the fault data were collected by Leonhard Rauch and Stefan Griesser in the frame of their bachelor thesis in the Falzthurn valley. We thank the journal referees Gerhard Bryda and Oscar Fernandez, who significantly contributed to the improvement of the manuscript.

\section{References}

Ampferer, O., 1902. Bericht über die Neuaufnahme des Karwendelgebirges. Verhandlungen der Geologischen Bundesanstalt, 1902, 274-276.

Ampferer, O., 1912. Gedanken über die Tektonik des Wettersteingebirges. Verhandlungen der k.k. Geologischen Reichsanstalt, 1912, 197-212.

Ampferer, O., 1914. Besprechung mit O. Schlagintweit, K. Ch. v. Loesch und H. Mylius über das Wettersteingebirge. Verhandlungen der k.k. Geologischen Reichsanstalt, 1914, 338-352.

Ampferer, O., 1928. Die Reliefüberschiebung des Karwendelgebirges. Jahrbuch der Geologischen Bundesanstalt, 78, 241-256.

Ampferer, O., 1931. Zur neuen Umgrenzung der Inntaldecke. Jahrbuch der Geologischen Bundesanstalt, 81, 25-48.

Ampferer, O., 1942. Geologische Formenwelt und Baugeschichte des östlichen Karwendelgebirges. Denkschriften der Akademie der Wissenschaft, 106/1, 1-95.

Ampferer, O., Hammer, W., 1911. Geologischer Querschnitt durch die Alpen vom Allgäu zum Gardasee. Jahrbuch der k.k. Geologischen Reichsanstalt, 61, 531-710.

Ampferer, O., Heißel, W., 1950. Das östliche Karwendel: Erläuterungen zur geologischen Karte des östlichen Karwendel und des Achensee-Gebietes. Wagner, Innsbruck, 55 pp.
Bachmann, G.H., Müller, M., 1981. Geologie der Tiefbohrung Vorderriß 1 (Kalkalpen, Bayern). Geologica Bavarica, 81, 17-53.

Biehler, D., 1990. Strukturelle Entwicklung der penninisch-ostalpinen Grenzzone am Beispiel der Arosa-Zone im Ost-Rätikon. Eclogae Geologicae Helvetiae, 83, $221-$ 402. https://doi.org/10.5169/seals-166585

Boyer, S.E., Elliott, D., 1982. Thrust systems. AAPG Bulletin, 66, 1196-1230.

Brandner, R., 2014. Die Karwendel-Plattform - ein Schlüssel zum Verständnis des Deckenbaues. In: Sonntag, H., Straubinger, F. (Eds.), Großer Ahornboden - eine Landschaft erzählt ihre Geschichte. Berenkamp, Wattens, 40-45.

Brühwiler, T., Hochuli, P.A., Mundil, R., Schatz, W., Brack, P., 2007. Bio- and chronostratigraphy of the Middle Triassic Reifling Formation of the westernmost Northern Calcareous Alps. Swiss Journal of Geosciences, 100, 443-455. https://doi.org/10.1007/s00015-007-1240-2

Costa, C.H., Gardini, C.E., Diederix, H., Cortés, J.M., 2000. The Andean orogenic front at Sierra de Las PeñasLas Higueras, Mendoza, Argentina. Journal of South American Earth Sciences, 13, 287-292. https://doi. org/10.1016/S0895-9811(00)00010-9

Dahlstrom, C.D.A., 1969. Balanced cross sections. Canadian Journal of Earth Sciences, 6, 743-757. https://doi. org/10.1139/e69-069

Decker, K., Faupl, P., Müller, A., 1987. Synorogenic sedimentation in the Northern Calcareous Alps during the Early Cretaceous. In: Faupl, P., Flügel, H.W. (Eds.), Geodynamics of the Eastern Alps. Deuticke, Wien, 126-141.

Decker, K., Peresson, H., Faupl, P., 1994. Die miozäne Tektonik der östlichen Kalkalpen: Kinematik, Paläospannungen und Deformationsaufteilung während der "lateralen Extrusion" der Zentralalpen. Jahrbuch der Geologischen Bundesanstalt, 137, 5-18.

Dewey, J.F., Helman, M.L., Turco, E., Hutton, D.H.W., Knott, S.D., 1989. Kinematics of the Western Mediterranean. In: Coward, M.P., Dietrich, D., Park, R.G. (Eds.), Alpine Tectonics. Special Publications. Geological Society, London, 45, pp. 265-283.

Dielforder, A., 2017. Constraining the strength of megathrusts from fault geometries and application to the Alpine collision zone. Earth and Planetary Science Letters, 474, 49-58. https://doi.org/10.1016/j. epsl.2017.06.021

Dielforder, A., Vollstaedt, H., Vennemann, T., Berger, A., Herwegh, M., 2015. Linking megathrust earthquakes to brittle deformation in a fossil accretionary complex. Nature Communications, 6, 7504. https://doi.org/10.1038/ ncomms8504

Doben, K. et al., 1991. Erläuterungen zum Blatt Nr. 8335 Lenggries. Geologische Karte von Bayern 1:25000. Bayerisches Geologisches Landesamt, München, $120 \mathrm{pp}$.

Donofrio, D.A., Heissel, G., Mostler, H., 1980. Beiträge zur Kenntnis der Partnachschichten (Trias) des Tor- und 
Rontales und zum Problem der Abgrenzung der Lechtaldecke im Nordkarwendel. Mitteilungen der Österreichischen Geologischen Gesellschaft, 73, 55-94.

Eisbacher, G.H., Brandner, R., 1995. Role of high-angle faults during heteroaxial contraction, Inntal thrust sheet, Northern Calcareous Alps, western Austria. Geologisch-Paläontologische Mitteilungen Innsbruck, 20, 389-406.

Eisbacher, G.H., Brandner, R., 1996. Superposed fold thrust structures and high angle faults, northwestern Calcareous Alps, Austria. Eclogae Geologicae Helvetiae, 89, 553-571. https://doi.org/10.5169/ seals-167913

Eisbacher, G.H., Linzer, G.-H., Meier, L., 1990. A depth extrapolated structural transect across the Northern Calcareous Alps of Western Tirol. Eclogae Geologicae Helvetiae, 83/3, 711-725. https://doi.org/10.5169/ seals- 166610

Fabricius, F., 1966. Beckensedimentation und Riffbildung an der Wende Trias/Jura in den Bayerisch-Tiroler Kalkalpen. International Sedimentary Petrological Series, 9. Brill, Leiden, $143 \mathrm{pp}$.

Faupl, P., Tollmann, A., 1979. Die Roßfeldschichten: Ein Beispiel für Sedimentation im Bereich einer tektonisch aktiven Tiefseerinne aus der kalkalpinen Unterkreide. Geologische Rundschau, 68/1, 93-120. https://doi. org/10.1007/bf01821124

Flügel, H., Fenninger, A., 1966. Die Lithogenese der Oberalmer Schichten und der mikritischen Plassenkalke (Tithonium, Nördliche Kalkalpen). Neues Jahrbuch für Geologie und Paläontologie, Abhandlungen, 123/3, 249-280.

Freudenberger, W., Schwerd, K., 1996. Erläuterungen zur geologischen Karte von Bayern 1:500 000. Bayerisches Geologisches Landesamt, München, 329 pp.

Froitzheim, N., Manatschal, G., 1996. Kinematics of Jurassic rifting, mantle exhumation, and passive-margin formation in the Austroalpine and Penninic nappes (eastern Switzerland). Geological Society of America Bulletin, 108, 1120 -1133. https://doi.org/10.1130/0016 -7606(1996)108<1120:KOJRME>2.3.CO;2

Froitzheim, N., Schmid, S., Conti, P., 1994. Repeated change from crustal shortening to orogen parallel extension in the Austroalpine units of Graubünden. Eclogae Geologicae Helvetiae, 87, 559-612. https://doi. org/10.5169/seals-167471

Froitzheim, N., Schmid, S.M., Frey, M., 1996. Mesozoic paleogeography and the timing of eclogite-facies metamorphism in the Alps: A working hypothesis. Eclogae Geologicae Helvetiae, 89, 81-110. https://doi. org/10.5169/seals-167895

Fruth, I., Scherreiks, R., 1982. Hauptdolomit (Norian), Stratigraphy, Paleogeography and Diagenesis. Sedimentary Geology, 32, 195-231. https://doi.org/ 10.1016/0037-0738(82)90050-1

Gaupp, R., 1982. Sedimentationsgeschichte der kalkalpinen Mittelkreide (Allgäu, Tirol, Vorarlberg). Zitteliana, 8, 33-72.
Haas, J., Kovács, S., Krystyn, L., Lein, R., 1995. Significance of Triassic facies zones in terrane reconstructions in the Alpine-North Pannonian domain. Tectonophysics, 242, 19-40. https://doi. org/10.1016/0040-1951(94)00157-5

Hahn, F.F., 1912. Versuch einer Gliederung der austroalpinen Masse westlich der österreichischen Traun. Verhandlungen der k. k. Geologischen Reichsanstalt, 1912, 337-344.

Hahn, F.F., 1913. Grundzüge des Baues der nördlichen Kalkalpen zwischen Inn und Enns. Mitteilungen der österreichischen Geologischen Gesellschaft, 9, 374-500.

Heißel, G., 1977. Die geologische Neuaufnahme des Karwendelgebirges und seine tektonische Ausdeutung. Doctoral Thesis, Universität Innsbruck, Innsbruck, $371 \mathrm{pp}$.

Heißel, G., 1978. Karwendel - geologischer Bau und Versuch einer tektonischen Rückformung. Geologisch-Paläontologische Mitteilungen Innsbruck, 8, 227-288.

Heißel, W., 1958. Zur Tektonik der Nordtiroler Kalkalpen. Mitteilungen der Österreichischen Geologischen Gesellschaft, 50, 95-132.

Höfle, H.-C. et al., 1969. Erläuterungen zum Blatt Nr. 8331 Baiersoien. Geologische Karte von Bayern 1:25000. Bayerisches Geologisches Landesamt, München, $122 \mathrm{pp}$.

Hudec, M.R., Jackson, M.P.A., 2007. Terra infirma: Understanding salt tectonics. Earth-Science Reviews, 82/1, 1-28. https://doi.org/10.1016/j.earscirev.2007.01.001

Jackson, M.P.A., Hudec, M.R., 2017. Salt Tectonics - Principles and Practice. Cambridge University Press, Cambridge, 510 pp. https://doi.org/10.1017/9781139003988

Jacobshagen, V., 1965. Die Allgäuschichten (Jura-Fleckenmergel) zwischen Wettersteingebirge und Rhein. Jahrbuch der Geologischen Bundesanstalt, 108, $1-114$.

Jeanbourquin, P., 1994. Early deformation of Ultrahelvetic mélanges in the Helvetic nappes (Western Swiss Alps). Journal of Structural Geology, 16, 1367-1383. https:// doi.org/10.1016/0191-8141(94)90003-5

Jerz, H., 1966. Untersuchungen über Stoffbestand, Bildungsbedingungen und Paläogeographie der Raibler Schichten zwischen Lech und Inn (Nördl. Kalkalpen). Geologica Bavarica, 56, 3-100.

Kusky, T.M., Bradley, D.C., 1999. Kinematic analysis of mélange fabrics: examples and applications from the McHugh Complex, Kenai Peninsula, Alaska. Journal of Structural Geology, 21, 1773-1796. https://doi. org/10.1016/S0191-8141(99)00105-4

Lein, R., 1987. Evolution of the Northern Calcareous Alps during Triassic times. In: Flügel, H.W., Faupl, P. (Eds.), Geodynamics of the Eastern Alps. Deuticke, Wien, 85-102.

Leitner, C., Spötl, C., 2017. Chapter 21 - The Eastern Alps: Multistage Development of Extremely Deformed Evaporites. In: Soto, J.I., Flinch, J.F., Tari, G. (Eds.), Permo-Triassic 
Salt Provinces of Europe, North Africa and the Atlantic Margins. Elsevier, 467-482.

Loesch, K.C.v., 1915. Der Schollenbau im Wetterstein- und Mieminger- Gebirge. Jahrbuch der k. k. Geologischen Reichsanstalt, 64 (1914), 1-98.

Mandl, G., 2000. The Alpine sector of the Tethyan shelf - examples for Triassic to Jurassic sedimentation and deformation from the Northern Calcareous Alps. Mitteilungen der Österreichischen Geologischen Gesellschaft, 92, 61-77.

Mandl, G.W., Brandner, R., Gruber, A., 2017. Zur Abgrenzung und Definition der Kalkalpinen Deckensysteme (Ostalpen, Österreich). In: Wimmer-Frey, I., Römer, A., Janda, C. (Eds.), Arbeitstagung 2017 - Angewandte Geowissenschaften an der GBA. Geologische Bundesanstalt, Wien, 254-255.

Moser, M., 2008. Provisorische Geologische Karte von Österreich, Blatt 118 - Innsbruck, GeoFAST 1:50.000. Geologische Bundesanstalt, Wien.

Müller-Jungbluth, W.-U., 1971. Sedimentologische Untersuchungen des Hauptdolomits der östlichen Lechtaler Alpen, Tirol. In: Mostler, H. (Ed.), Beiträge zur Mikrofazies und Stratigraphie von Tirol und Vorarlberg, Festband des Geol. Inst., 300-Jahr-Feier Univ. Innsbruck, Innsbruck, 255-308.

Mylius, H., 1914. Berge von scheinbar ortsfremder Herkunft in den bayrischen Alpen. Landeskundliche Forschungen, 22, 1-44.

Nagel, K.H., Schütz, K.I., Schütz, S., Wilmers, W., Zeil, W., 1976. Die geodynamische Entwicklung der Thiersee- und Karwendelmulde (Nördliche Kalkalpen). Geologische Rundschau, 65, 536-557. https://doi. org/10.1007/BF01808480

Needham, D.T., 1995. Mechanisms of mélange formation: examples from SW Japan and southern Scotland. Journal of Structural Geology, 17, 371-388. https://doi. org/10.1016/0191-8141(94)00132-J

Nittel, P., 2006. Beiträge zur Stratigraphie und Mikropaläontologie der Mitteltrias der Innsbrucker Nordkette (Nördliche Kalkalpen, Austria). Geo.Alp, 3, 93-145.

Ortner, H., 2001. Growing folds and sedimentation of the Gosau Group, Muttekopf, Northern Calcareous Alps, Austria. Int. J. Earth Sci. (Geol. Rundsch.), 90, 727-739. https://doi.org/10.1007/s005310000182

Ortner, H., 2003a. Cretaceous thrusting in the western part of the Northern Calcareous Alps (Austria) - evidences from synorogenic sedimentation and structural data. Mitteilungen der Österreichischen Geologischen Gesellschaft, 94, 63-77.

Ortner, H., 2003b. Local and far field stress - analysis of brittle deformation in the western part of the Northern Calcareous Alps, Austria. Geologisch-Paläontologische Mitteilungen Innsbruck, 26, 109-131.

Ortner, H., 2016. Field Trip 4: Deep water sedimentation on top of a growing orogenic wedge - interaction of thrusting, erosion and deposition in the Cretaceous Northern Calcareous Alps. Geo.Alp, 13, 141-182.

Ortner, H., Bitterlich, L., 2016. The Zugsitze cross section and the structure of the Northern Calcareous Alps.
In: Ortner, H. (Ed.), Abstract Volume of GeoTirol2016 Annual Meeting of DGGV and PANGEO Austria. Institute of Geology, University of Innsbruck, Innsbruck, 248.

Ortner, H., Gaupp, R., 2007. Synorogenic sediments of the western Northern Calcareous Alps. Geo.Alp, 4, 133-148.

Ortner, H., Kilian, S., 2016. Sediment creep on slopes in pelagic limestones: Upper Jurassic of Northern Calcareous Alps, Austria. Sedimentary Geology, 350-363. https://doi.org/10.1016/j.sedgeo.2016.03.013

Ortner, H., Kositz, A., Willingshofer, E., Sokoutis, D., 2016. Geometry of growth strata in a transpressive fold belt in field and analogue model: Gosau Group at Muttekopf, Northern Calcareous Alps, Austria. Basin Research, 28/6, 731-751. https://doi.org/10.1111/bre.12129

Ortner, H., Reiter, F., Acs, P., 2002. Easy handling of tectonic data: the programs TectonicVB for Mac and TectonicsFP for Windows(TM). Computers \& Geosciences, 28, 1193-1200. https://doi.org/10.1016/ S0098-3004(02)00038-9

Ortner, H., Reiter, F., Brandner, R., 2006. Kinematics of the Inntal shear zone-sub-Tauern ramp fault system and the interpretation of the TRANSALP seismic section, Eastern Alps, Austria. Tectonophysics, 414, 241-258. https://doi. org/10.1016/j.tecto.2005.10.017

Ortner, H., Stingl, V., 2001. Facies and Basin Development of the Oligocene in the Lower Inn Valley, Tyrol/ Bavaria. In: Piller, W., Rasser, M. (Eds.), Paleogene in Austria. Schriftenreihe der Erdwissenschaftlichen Kommissionen, 14. Österreichische Akademie der Wissenschaften, Wien, 153-196.

Oswald, P., Ortner, H., Gruber, A., 2018. Deformation around a detached half-graben shoulder during nappe stacking (Northern Calcareous Alps, Austria). Swiss Journal of Geosciences. https://doi.org/10.1007/ s00015-018-0333-4

Peresson, H., Decker, K., 1997. The Tertiary dynamics of the northern Eastern Alps (Austria): changing palaeostresses in a collisional plate boundary. Tectonophysics, 272, 125-157. https://doi.org/10.1016/ S0040-1951(96)00255-7

Pestal, G., Hejl, E., Braunstingl, R., Schuster, R., 2009. Geologische Karte von Salzburg 1:200 000: Erläuterungen. Geologische Bundesanstalt, Wien, 162 pp.

Ramsay, J.G., 1960. The deformation of early linear structures in areas of repeated folding. The Journal of Geology, 68/1, 75-93.

Reiter, F. et al., 2018. Active seismotectonic deformation in front of the Dolomites indenter, Eastern Alps. Tectonics, 37/12, 4625-4654. https://doi. org/10.1029/2017TC004867

Richter, M., 1928. Ein neues Vorkommen von Diabasen im Karwendel. Verhandlungen der Geologischen Bundesanstalt, 1928, 117-120.

Richter, M., 1929. Die Struktur der nördlichen Kalkalpen zwischen Rhein und Inn. Neues Jahrbuch für Mineralogie, Geologie und Paläontologie, Beilage-Band, 63, Abteilung $B, 1-62$. 
Ring, U., Ratschbacher, L., Frisch, W., 1988. Plate Boundary Kinematics in the Alps: Motion in the Arosa Suture Zone. Geology, 16, 696-698. https://doi.org/10.1130/0091-76 13(1988)016<0696:PBKITA>2.3.CO;2

Ring, U., Ratschbacher, L., Frisch, W., Dürr, S., Borchert, S., 1990. The internal structure of the Arosa Zone. Geologische Rundschau, 79, 725-739. https://doi. org/10.1007/BF01879211

Rüffer, T., Bechstädt, T., 1995. Interpretation des Deckenbaus in den westlichen nördlichen Kalkalpen: Widerspruch zwischen tektonischen und sedimentologischen Daten. Jahrbuch der Geologischen Bundesanstalt, 138, 701-713. Rüffer, T., Zamperelli, V., 1997. Facies and Biota of Anisian to Carnian Carbonate Platforms in the Northern Calcareous Alps (Tyrol and Bavaria). Facies, 37, 115-136. https:// doi.org/10.1007/BF02537374

Sarnthein, M., 1966. Sedimentologische Profilreihen aus den mitteltriadischen Karbonatgesteinen der Kalkalpen nördlich und südlich von Innsbruck. 1. Fortsetzung. Berichte des naturwissenschaftlich-medizinischen Vereins Innsbruck, 54, 33-59.

Sarnthein, M., 1967. Versuch einer Rekonstruktion der mitteltriadischen Paläogeographie um Innsbruck. Österreich. Geologische Rundschau, 56/1, 116-127. https://doi.org/10.1007/bf01848710

Schlager, W., Schöllnberger, W., 1974. Das Prinzip stratigraphischer Wenden in der Schichtfolge der Nördlichen Kalkalpen. Mitteilungen der Österreichischen Geologischen Gesellschaft, 66/67, 165-193.

Schlagintweit, O., 1912a. Die Mieminger-Wetterstein Überschiebung. Geologische Rundschau, 3/2, 73-92.

Schlagintweit, O., 1912b. Zum Problem des Wettersteingebirges. Verhandlungen der k. k. Geologischen Reichsanstalt, 1912, 313-327.

Schmid, S.M., Fügenschuh, B., Kissling, E., Schuster, R., 2004. Tectonic map and overall architecture of the Alpine orogen. Eclogae Geologicae Helvetiae, 97, 93-117. https://doi.org/10.1007/s00015-004-1113-x

Schmidegg, O., 1950. Die Stellung der Haller Salzlagerstätte im Bau des Karwendelgebirges. Jahrbuch der Geologischen Bundesanstalt, 94, 159-205.

Schmidt, S., Hetzel, R., Mingorance, F., Ramos, V.A., 2011. Coseismic displacements and Holocene slip rates for two active thrust faults at the mountain front of the Andean Precordillera $\left(\sim 33^{\circ} \mathrm{S}\right)$. Tectonics, 30/5. https:// doi.org/10.1029/2011TC002932

Spang, J.H., 1972. Numerical method for dynamic analysis of calcite twin lamellae. Geological Society of America Bulletin, 83/1, 467-472. https://doi.org/10.1130/0016-7 606(1972)83[467:NMFDAO]2.0.CO;2

Spötl, C., 1988. Sedimentologisch-fazielle Analyse tektonisierter Evaporitserien - eine Fallstudie des Alpinen Haselgebirges (Permoskyth, Nördliche Kalkalpen). Geologisch-Paläontologische Mitteilungen Innsbruck, 15, 59-69.

Stampfli, G.M. et al., 1998. Subduction and obduction processes in the Swiss Alps. Tectonophysics, 296, 159-204. https://doi.org/10.1016/S0040-1951(98)00142-5
Steiger, T., 1981. Kalkturbidite im Oberjura der Nördlichen Kalkalpen (Barmsteinkalke, Salzburg, Österreich). Facies, 4, 215-348.

Stüwe, K., Schuster, R., 2010. Initiation of subduction in the Alps: Continent or ocean? Geology, 38, 175-178. https://doi.org/10.1130/G30528.1

Suppe, J., 1983. Geometry and kinematics of fault-bend folding. American Journal of Science, 283, 684-721. https://doi.org/10.2475/ajs.283.7.684

Tanner, D.C., Behrmann, J.H., Dresmann, H., 2003. Three-dimensional retrodeformation of the Lechtal nappe, Northern Calcareous Alps. Journal of Structural Geology, 25, 737-748. https://doi.org/10.1016/ S0191-8141(02)00057-3

Tobin, H.J., Moore, J.C., Moore, G.F., 1994. Fluid pressure in the frontal thrust of the Oregon accretionary prism: Experimental constraints. Geology, 22/11, 979-982. https://doi. org/10.1130/0091-7613(1994)022<0979:FPITFT>2.3.CO;2

Tollmann, A., 1970. Tektonische Karte der Nördlichen Kalkalpen, 3. Teil: Der Westabschnitt. Mitteilungen der Österreichischen Geologischen Gesellschaft, 62 (1969), 78-170.

Tollmann, A., 1973. Grundprinzipien der alpinen Deckentektonik. Monographie der Nördlichen Kalkalpen, Teil I. Deuticke, Wien, 404 pp.

Tollmann, A., 1976a. Analyse des klassischen nordalpinen Mesozoikums. Monographie der Nördlichen Kalkalpen, Teil II. Deuticke, Wien, 580 pp.

Tollmann, A., 1976b. Der Bau der Nördlichen Kalkalpen. Monographie der Nördlichen Kalkalpen, Teil III. Deuticke, Wien, 449 pp.

Trommsdorff, V., Dietrich, V., Flisch, M., Stille, P., Ulmer, P., 1990. Mid - Cretaceous, primitive alkaline magmatism in the Northern Calcareous Alps: significance for Austroalpine geodynamics. Geologische Rundschau, 79/1, 85-97. https://doi.org/10.1007/BF01830448

Vergés, J. et al., 2007. Crustal wedging triggering recent deformation in the Andean thrust front between $31^{\circ} \mathrm{S}$ and $33^{\circ} \mathrm{S}$ : Sierras Pampeanas-Precordillera interaction. Journal of Geophysical Research, 112(B03), B03S15. https://doi.org/10.1029/2006JB004287

Wilmers, W., 1971. Geologie der Mulde von Thiersee zwischen Landl und Kufstein in Tirol (Nördliche Kalkalpen). Doctoral Thesis, TU Berlin, Berlin, 75 pp.

Received: 28012019

Accepted: 16052019

\section{Sinah KILIAN \& Hugo ORTNER}

Institute of Geology, University of Innsbruck, Innrain 52, 6020 Innsbruck, Austria;

Corresponding author: Sinah.Kilian@student.uibk.ac.at 